\title{
clinical trial of Adfroben, a topical application of Flurbiprofen, in the field of orthopedic surgery
}

整形外科領域に括けるフルルビプロフェン

含有貼付剤アドフロベンの臨床的検討

二重盲検交差試験による基剤との比較—

\section{drug evaluation *}

七川歓次, 小松原良雄, 木村正己 辻本正記・水島 裕 $\cdot$ 中島 章
整形外科領域において, 日常診療する機会の多い, 疼 痛を主訴とする疾患には, 変形性関節症, 関節炎, 腱周 囲炎などの広義の慢性りウマチ病から挫傷, 捻挫などの 外傷性疾患にいたるまで多くの疾患がある.

これらの患者の疼痛に対しては, 非ステロイド抗炎症 鎮痛剂の内服や坐剂の有用性が認められているが, 症状 が限局されている場合には, 患部への直接作用を期待し た局所投与が，全身的影響も少なく，有効な治療法では ないかと考えられる。

この目的で, われわれはフルルビプロフェンを局所療 法に応用した貼付剤アドフロベンの臨床効果を, オープ ントラィアルで検討した ${ }^{6)}$. その結果, この貼付剂は非 外傷性疼痛疾患に対し $72.0 \%$, 外傷性疼痛疾患に対し $87.5 \%$ と高い有效率を示し, 安全性も高く, 有用性のあ る製剤と考えられた。

引き続き本二重盲検試験を実施するにあたり，評価方 法の確認のため, 予備試験として基剤を対照とした小規 模二重盲検交差試験を実施した.

今回は, これらの試験結果に基づき,さらに規模を拡 大して, 基剤のみからなる製剂を対照とした多施設二重 盲検交差試験を行い, アドフロベンの有効性, 安全性, 有用性を検討したので，その結果を報告する。

\section{方 法}

本二重盲検試験 は, 七川歓次，小松原良雄，木村正 己, 辻本正記, 4 名の世話人により検討, 立案され, 表 1 に示す参加 14 施設の了解を得て, 実施された. コン トローラーは, 聖マリアンナ医科大学第一内科 水島裕 （第 1 コントローラー）と順天堂大学医学部眼科 中島章

\section{本欄の執筆者}

七川歓次：滋賀医科大学整形外科学教室

小松原良雄 : 大阪府立成人病センター整形外科

木村正已：住友病院整形外科

过本正記 : 大阪労災病院整形外科

第1コントローラー

水島 裕: 聖マリアンナ医科大学第一内科学教室

第 2 コントローラー

中島 章 : 順天堂大学医学部眼科学教室
（第 2 コントローラー）が担当した

(1) 対象患者

昭和56年 4 月から 8 月までに表 1 に示した施設を受診 した変形性関節症, 関節周囲炎, 腱鞘炎などの持続性有 痛疾患の患者のらち，本試験の趣旨を理解し，参加の同 意が得られたものを対象とした。

ただし，つぎの患者は対象から除外した。

(1) 皮膚疾患患者および過敏症の既往のある患者.

(2) 疼痛が, 自然治癒する傾向のある外傷性疾患, 全 身性の炎症性疾患, および感染症に起因すると思われる 疾患患者.

(3) そのほか, 主治医が不適当と判断した患者.

(2) 試験薬剤

アドフロベン（以下 FP）は $13.6 \times 10 \mathrm{~cm}$ の白布にフ ルルビプロフェン $40 \mathrm{mg}$ を含有する亳体を均一に展延し た貼付凨である.

対照薬はフルルビプロフェンを含まない基剤のみの貼 付剂（以下 $\mathrm{P}$ ）を用いた。

試験に供した被験薬と対照薬の外観上の識別不能性に ついては，コントローラーにより保証され，また星薬科 大学薬剂学教室 永井恒司教授に依頼し, 抜き取り検查 による製剤試験の結果，規格に適合していることが確認 された。

なお，これらの試験薬剤は科研薬化工株式会社から提 供を受けた。

（3）試験デザインおよび割り付け

1 日の休薬期間を竹いて, 前 6 日間の第 1 治療期（以 下第 1 期) と後 6 日間の第 2 治療期(以下第 2 期)を設定 乙, 第 1 期に第 1 治療薬 (以下第 1 薬), 第 2 期に第 2 治 療薬(以下第 2 薬)を投与する交差試験を行った(図 1 ).

投与した薬剂順序が「 F P $\rightarrow \mathrm{P} 」$ の組み合わせを第 1 組，「P $\rightarrow$ F P」を第 2 組とした。薬剤は第 1 コントロ ーラーと第 2 コントローラーにより無作為に割り付けら れ, key table はそれぞれのコントローラーが保管した.

(4) 投与方法

試験デザインに従って，薬剤を 1 日 2 回 (朝・晚), 患部に 1 枚貼付させ, 同時に 2 枚使用したり, 半分に切 
表 1 参加施設

\begin{tabular}{|c|c|c|c|}
\hline 設 & & 名 & 医＼cjkstart師＼cjkstart名（敬称略） \\
\hline 滋 賀 医 科 大 & 学 & 整 形 外 科 & 七川歓次, 西岡淳一, 武仲善孝, 泉類博明 \\
\hline 大阪府立成人病センタ & - & 整 形 外 科 & 小松原良雄 \\
\hline 住友病 & 院 & 整 形 外 科 & 木 村 正已 \\
\hline 大阪 労 災 病 & 院 & 整 形 外 科 & 辻本 正 記 \\
\hline 浅 香 山 病 & 院 & 整形外科 & 中根勇 平 \\
\hline 市 立 泉 佐 野 病 & 院 & 整 形 外 科 & 岡山 孝 \\
\hline 市 立 貝 塚 病 & 院 & 整 形 外 科 & 田中稠久 \\
\hline 市＼cjkstart立＼cjkstart堺＼cjkstart病 & 院 & 整 形 外 科 & 本 郷一 郎 \\
\hline 大阪船員保険病 & 院 & 整 形 外 科 & 岩崎南海雄 \\
\hline 大 阪 鉄 道 病 & 院 & 整 形 外 科 & 大田＼cjkstart寛 \\
\hline 関 西 労 災 病 & 院 & 整 形 外 科 & 折原正美, 赤 堀 修 \\
\hline 国立大阪 南 病 & 院 & 整 形 外 科 & 前 田＼cjkstart晃，大西啓靖 \\
\hline 阪 和 泉 北 病 & 院 & 整 形 外 科 & 吉岡康裕, 重本裕子. 井川義亮, 前田邦雄 \\
\hline 八 尾 市 立 & 院 & 整 形 外 科 & 中田 森 男 \\
\hline
\end{tabular}

\begin{tabular}{|l|l|l|l|l|l|l|l|l|l|l|l|l|l|l|} 
治療日数 & 1 & 2 & 3 & 4 & 5 & 6 & 7 & 8 & 9 & 10 & 11 & 12 & 13 & 14 \\
\hline
\end{tabular}

第 1 治療期（第 1 治療薬）

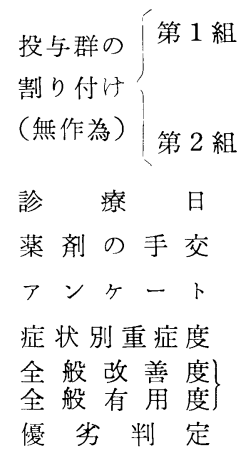

第 2 治療期（第 2 治療薬）

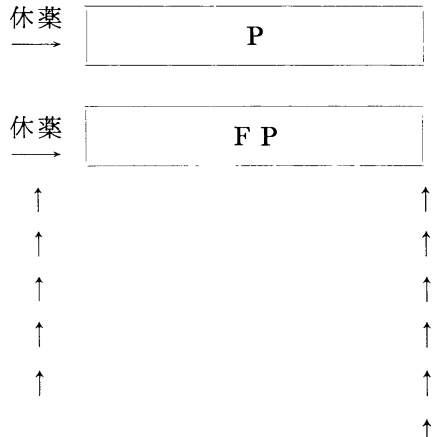

図 1 試験デザイン

って使用するのは禁じた。

また，第 1 薬を第 2 期にまたがって使用しないよう， 第 2 薬は第 1 期終了後に投薬することとした.

（5）併用療法

抗炎症剂の内服およびステロイドの関節注入は避け た. 理学療法は, 試験中新たに追加して行らことは避け たが，試験開始前より行っているものに限り，条件を変 えずに継続させた。

(6) 評価方法

(1) 症状別重症度

7 項目の症状（自発痛, 圧痛, 運動痛, 局所熱感, 腫 脹, 運動制限, 筇緊張) につき, 開始時, 第 1 期終了 時, 第 2 期終了時に重症度を 4 段階（高度, 中等度, 軽 度, 症状なし）で評価した。

\section{(2) 全般改善度}

開始時と第 1 期終了時および第 2 期終了時の症状別重 症度の変化を 総合的に考慮して, 全般改善度を 7 段階
表 2 解析対象例数 (総症例数: 221 例中)

\begin{tabular}{c|c|c|c|c}
\hline \multirow{2}{*}{ 薬剤組 } & \multicolumn{2}{|c|}{ 第 1 治療期 } & \multicolumn{2}{|c}{ 第 2 治療期 } \\
\cline { 2 - 4 } & 解析対象例数 & 除外例数 & 解析対象例数 & 除外例数 \\
\hline 第 1 組 & ( F P 投与) & \multicolumn{2}{|c|}{ ( P 投与) } \\
\hline$(112$ 例) & 109 & 3 & 101 & 12 \\
\hline 第 2 組 & ( P 投与) & ( F P 投与) \\
\hline (109例) & 101 & 8 & 90 & 19 \\
\hline 計 & 210 & 11 & 190 & 31 \\
\hline
\end{tabular}

(著明改善, 改善, 軽度改善, 不変, 軽度悪化, 悪化, 重篤に悪化）で判定した。

(3) 副作用および概括安全度

副作用が発現した症例については, 種類, 程度, 処置 などを明記した。また臨床検査は投与前後に血液検査, 血液生化学検査, 尿検査などを可能な限り実施した。 
表 3 除外例

\begin{tabular}{|c|c|c|c|}
\hline \multirow{2}{*}{ 薬 㨈 組 } & \multirow{2}{*}{ 理 由 } & \multicolumn{2}{|c|}{ 例 数 } \\
\hline & & 第 1 治療期 & 第 2 治療期 \\
\hline \multirow[t]{2}{*}{$\begin{array}{c}\text { 第 } 1 \text { 組 } \\
(\mathrm{F} \mathrm{P} \rightarrow \mathrm{P})\end{array}$} & $\begin{array}{l}\text { 全身の炎症性疾患（RA）を合併している。 } \\
\text { 薬剤を半分に切って投与期間を引き趆ばしている。 } \\
\text { 第 } 1 \text { 治療薬で悪化したため, 第 } 2 \text { 治療薬は手交せず. } \\
\text { 第 } 1 \text { 治療薬で治療したため, 第 } 2 \text { 治療薬は手交せず。 } \\
\text { 第 } 1 \text { 治療薬で副作用が発現したため, 第 } 2 \text { 治療薬は手交せず. } \\
\text { 家庭の都合により来院せず. } \\
\text { 開始日以来, 再来院せず, 第 } 2 \text { 治療薬は手交せず. }\end{array}$ & $\begin{array}{l}2 \\
1 \\
0 \\
0 \\
0 \\
0 \\
0\end{array}$ & $\begin{array}{l}2 \\
1 \\
1 \\
2 \\
2 \\
1 \\
3\end{array}$ \\
\hline & （小 計） & 3 & 12 \\
\hline \multirow[t]{2}{*}{$\begin{array}{c}\text { 第 } 2 \text { 組 } \\
(\mathrm{P} \leftarrow \mathrm{F} P)\end{array}$} & 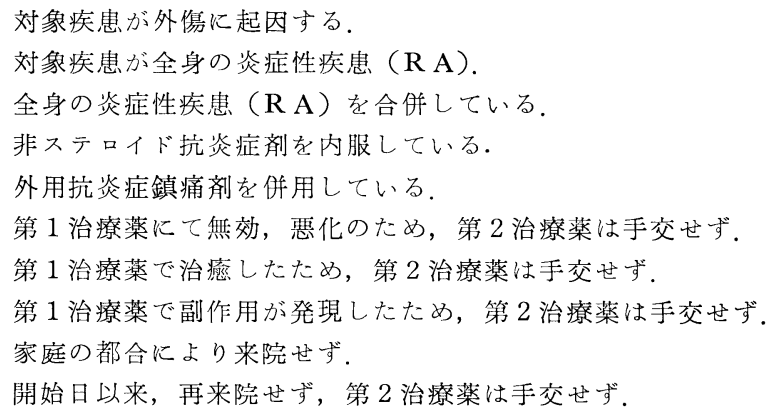 & $\begin{array}{l}1 \\
1 \\
2 \\
3 \\
1 \\
0 \\
0 \\
0 \\
0 \\
0\end{array}$ & $\begin{array}{l}1 \\
1 \\
2 \\
3 \\
1 \\
3 \\
2 \\
1 \\
1 \\
4\end{array}$ \\
\hline & （小 計） & 8 & 19 \\
\hline & 計 & 11 & 31 \\
\hline
\end{tabular}

表 4 脱落例

\begin{tabular}{|c|c|c|c|}
\hline \multirow{2}{*}{ 薬 剤 組 } & \multirow{2}{*}{ 理 由 } & \multicolumn{2}{|c|}{ 例 数 } \\
\hline & & 第 1 治療期 & 第 2 治療期 \\
\hline \multirow[t]{2}{*}{$\begin{array}{c}\text { 第 } 1 \text { 組 } \\
(\mathrm{F} \mathrm{P} \rightarrow \mathrm{P})\end{array}$} & $\begin{array}{l}\text { 来院せず. } \\
\text { 副作用 (かぶれ) のため } 3 \text { 日目に投薬中止*. } \\
\text { 病歴が } 1 \text { 週未満, 判定不能*. }\end{array}$ & $\begin{array}{l}4 \\
1 \\
2\end{array}$ & $\begin{array}{l}4 \\
0 \\
1\end{array}$ \\
\hline & （小 計） & 7 & 5 \\
\hline \multirow[t]{2}{*}{$\begin{array}{c}\text { 第 } 2 \text { 組 } \\
(\mathrm{P} \rightarrow \mathrm{F} P)\end{array}$} & $\begin{array}{l}\text { 来院せず. } \\
\text { 投薬が不十分のために判定不能. } \\
\text { 病歴が } 1 \text { 週未満, 判定不能*. }\end{array}$ & $\begin{array}{l}3 \\
0 \\
3\end{array}$ & $\begin{array}{r}10 \\
2 \\
3\end{array}$ \\
\hline & (小 計) & 6 & 15 \\
\hline & 計 & 13 & 20 \\
\hline
\end{tabular}

* 概括安全度の評価の対象に含む。

概括安全度は，副作用の発生状沉により，3 段階（副作 用なし，軽い副作用で投与継続，副作用のため 投与中 止）で判定した。

\section{(4) 全般有用度および医師の優劣判定}

全般改善度と概括安全度を考慮して，第 1 薬，第 2 薬 別に全般有用度を 7 段階（きわめて有用，有用，やや有 用, 有用性なし, やや有害, 有害, きわめて有害) で判
定した。

また，医師の優劣判定は同一患者内で第 1 薬と第 2 薬 を比較してどちらが有用であるかをつぎの 7 段階で判定 した。

第 1 薬が非常に有用，第 1 薬が有用，第 1 薬がやや有 用, どちらともいえない, 第 2 薬がやや有用, 第 2 薬が 有用, 第 2 薬が非常に有用. 
表 5 北景因子

\begin{tabular}{|c|c|c|c|c|c|}
\hline \multicolumn{2}{|c|}{ 項 } & $\begin{array}{c}\text { 第 } 1 \text { 期 } \\
(\mathrm{F} \mathrm{P} \rightarrow \mathrm{P})\end{array}$ & $\begin{array}{c}\text { 第 } 2 \text { 期 } \\
(\mathrm{P} \rightarrow \mathrm{E} \mathrm{P})\end{array}$ & 㝇 & 㭘 \\
\hline \multicolumn{2}{|c|}{ 総 } & 112 & 109 & 221 & \\
\hline \multirow{2}{*}{ 性 } & 男 & 27 & 29 & 56 & \multirow{2}{*}{$\begin{array}{c}\chi^{2} \text { test } \\
\mathrm{N} \mathrm{S}\end{array}$} \\
\hline & 女 & 85 & 80 & 165 & \\
\hline \multirow{7}{*}{ 年 齢 } & $\sim 19$ & 2 & 4 & 6 & \multirow{7}{*}{$\begin{array}{l}\text { U test } \\
\mathrm{N} \mathrm{S}\end{array}$} \\
\hline & $20 \sim 29$ & 5 & 10 & 15 & \\
\hline & $30 \sim 39$ & 8 & 12 & 20 & \\
\hline & $40 \sim 49$ & 26 & 19 & 45 & \\
\hline & $50 \sim 59$ & 32 & 18 & 50 & \\
\hline & $60 \sim 69$ & 24 & 30 & 54 & \\
\hline & $70 \sim$ & 15 & 16 & 31 & \\
\hline \multirow{2}{*}{ 入院外来 } & 院 & 6 & 5 & 11 & \multirow{2}{*}{$\begin{array}{c}\chi^{2} \text { test } \\
\text { N S }\end{array}$} \\
\hline & 外院 & 106 & 104 & 210 & \\
\hline \multirow{7}{*}{ 疾患分類 } & 変形性関節症 & 34 & 23 & 57 & \multirow{7}{*}{$\begin{array}{c}\chi^{2} \text { test } \\
\text { N S }\end{array}$} \\
\hline & 肩関節周囲炎 & 26 & 28 & 54 & \\
\hline & 肘関節周囲炎 & 12 & 11 & 23 & \\
\hline & その他の関節周囲炎 & 4 & 3 & 7 & \\
\hline & 腱 鞘 炎 & 18 & 17 & 35 & \\
\hline & 頸肩腕症候群 & 9 & 11 & 20 & \\
\hline & そ の 他 & 9 & 16 & 25 & \\
\hline \multirow{3}{*}{ 重 症 度 } & 軽症 & 45 & 50 & 95 & \multirow{3}{*}{$\begin{array}{c}\text { U test } \\
\text { N S }\end{array}$} \\
\hline & 中 等 症 & 60 & 56 & 116 & \\
\hline & 重症 & 7 & 3 & 10 & \\
\hline \multirow{3}{*}{ 現 病 歴 } & $\sim 1$ 力月 & 40 & 45 & 85 & \multirow{3}{*}{$\begin{array}{c}\text { U test } \\
\text { N S }\end{array}$} \\
\hline & $\sim 6$ 力月 & 47 & 37 & 84 & \\
\hline & 6 力月〜 & 25 & 27 & 52 & \\
\hline \multirow{4}{*}{ 合 併 症 } & な し & 83 & 88 & 171 & \multirow{4}{*}{$\begin{array}{c}\chi^{2} \text { test } \\
\text { N S }\end{array}$} \\
\hline & 慢性関節リウマチ & 2 & 2 & 4 & \\
\hline & 整形外科疾患 & 15 & 8 & 23 & \\
\hline & その他の疾患 & 12 & 11 & 23 & \\
\hline \multirow{3}{*}{ 貼付部位 } & 上 肢 & 30 & 27 & 57 & \multirow{3}{*}{$\begin{array}{c}\chi^{2} \text { test } \\
\text { N S }\end{array}$} \\
\hline & 軀 幹 部 位 & 37 & 47 & 84 & \\
\hline & 下 肢 & 45 & 35 & 80 & \\
\hline \multirow{4}{*}{ 併 用薬 } & な & 110 & 103 & 213 & \multirow{4}{*}{$\begin{array}{c}\chi^{2} \text { test } \\
\mathrm{N} \mathrm{S}\end{array}$} \\
\hline & 抗炎症鎮痛剤の内服 & 0 & 3 & 3 & \\
\hline & 抗炎症鎮痛剂の外用 & 0 & 1 & 1 & \\
\hline & その他の併用薬 & 2 & 2 & 4 & \\
\hline
\end{tabular}

\section{(5) 患者の評価}

第 1 期, 第 2 期終了時にアンケート用紙を配り, 患部 の昼間の痛み, 患部の夜間の痛及, 压迫痛, 患部の可動 性, 筋肉にこわばり, 日常生活, 総合評価, の7 項目に つき, 開始時に比べてどれだけ改善したかを 5 段階（己 善, やや改善, 不変, やや悪化, 悪化) で判定させた. また，第 2 期終了時には，患者の優劣判定として，第
1 薬と第 2 薬を比較させ，つぎの 5 段階で判定させた。

第 1 薬が優れている，第 1 薬がやや優れている，どち らともいえない，第 2 薬がやや優れている，第 2 薬が優 れている。

(7) 除外・脱落

回収された患者記録用紙は，コントローラー同席のも とで世話人会において吟味し, 協議し, 中央判定として 
1）群間比較

表 6 全般改善度

\begin{tabular}{|c|c|c|c|c|c|c|c|c|c|c|c|c|c|c|c|}
\hline 治 & 薬 & \multicolumn{7}{|c|}{ 全 般 改善 度 } & 脱 & & \multicolumn{4}{|c|}{$\chi^{2}$ test } & \multirow{3}{*}{$\mathrm{U}$ test } \\
\hline 療 & & & 改 & & & & 悪 & 重覀 & & 計 & & 善 & 軽 & 改善 & \\
\hline 期 & 剤 & 明善 & 善 & 度善 & 変 & 度化 & 化 & 飞化 & 落 & & $\%$ & & $\%$ & & \\
\hline $\begin{array}{l}\text { 第治 } \\
\text { 療 } \\
1 \text { 期 }\end{array}$ & $\begin{array}{c}\text { F P } \\
\text { P }\end{array}$ & 3 & 16 & 52 & 31 & 2 & 0 & 0 & 7 & 109 & 24 & N S & $\begin{array}{l}72 \\
60\end{array}$ & N S & $\begin{array}{c}\mathrm{F} \mathrm{P}>\mathrm{P} \\
+\end{array}$ \\
\hline $\begin{array}{l}2 \text { 治 } \\
\text { 療 } \\
\text { 第期 }\end{array}$ & F P & 7 & 29 & 31 & 12 & 1 & 0 & 0 & 15 & 100 & 40 & N S & $\begin{array}{l}74 \\
80\end{array}$ & N S & $\begin{array}{c}\mathrm{F} \mathrm{P}>\mathrm{P} \\
+\end{array}$ \\
\hline
\end{tabular}

2）患者内薬剂比較

\begin{tabular}{|c|c|c|c|c|c|c|c|c|c|c|c|c|}
\hline \multicolumn{4}{|c|}{ F P } & \multicolumn{3}{|c|}{$\mathrm{P}$} & \multirow{2}{*}{ 脱 落 } & \multirow{2}{*}{ 計 } & \multirow{2}{*}{$>\%$} & \multirow{2}{*}{$<\%$} & \multirow{2}{*}{ S-test } & \multirow{2}{*}{$\mathrm{W}$-test } \\
\hline$\gg \gg$ & $\gg$ & $>$ & $=$ & $<$ & $\ll$ & $\ll<$ & & & & & & \\
\hline 1 & 5 & 55 & 75 & 29 & 5 & 0 & 20 & 190 & 32 & 18 & $\underset{* *}{\mathrm{~F}} \underset{ }{\mathrm{P}}>\mathrm{P}$ & $\underset{*}{\mathrm{~F}} \mathrm{P}>\mathrm{P}$ \\
\hline
\end{tabular}

3）患者内時期比較

\begin{tabular}{|c|c|c|c|c|c|c|c|c|c|c|c|c|}
\hline \multicolumn{5}{|c|}{ 第 1 治療期 } & \multicolumn{2}{|c|}{ 第 2 治療期 } & \multirow{2}{*}{ 脱 落 } & \multirow{2}{*}{ 計 } & \multirow{2}{*}{$>\%$} & \multirow{2}{*}{$<\%$} & \multirow{2}{*}{ S-test } & \multirow{2}{*}{$\mathrm{W}$-test } \\
\hline$\gg \gg$ & $\gg$ & $>$ & $=$ & $<$ & $\ll$ & $\ll<$ & & & & & & \\
\hline 0 & 2 & 18 & 75 & 66 & 8 & 1 & 20 & 190 & 11 & 39 & $\begin{array}{c}\text { 第 } 1 \\
\text { 治療 }<\text { 治 } 2 \\
\text { 海療 } \\
\text { 期 } \\
* * *\end{array}$ & $\mid \begin{array}{cc}\text { 第 } 1 & \text { 第 } 2 \\
\text { 治療 } & \text { 治療 } \\
\text { 期 } & \text { 期 } \\
* * *\end{array}$ \\
\hline
\end{tabular}

表 7 概括安全度 (群間比較)

\begin{tabular}{|c|c|c|c|c|c|c|c|c|c|}
\hline \multirow[b]{2}{*}{ 治 療 期 } & \multirow[b]{2}{*}{ 薬 剂 } & \multicolumn{3}{|c|}{ 概 括 安 全 度 } & \multirow[b]{2}{*}{ 脱 落 } & \multirow[b]{2}{*}{ 合 計 } & \multirow[b]{2}{*}{$\begin{array}{c}\text { 発現率 } \\
(\%)\end{array}$} & \multirow[b]{2}{*}{$\chi^{2}$ test } & \multirow[b]{2}{*}{$\mathrm{U}$ test } \\
\hline & & $\begin{array}{ll}\text { 副 } & \text { 作 用 } \\
\text { な } & \text { L }\end{array}$ & $\begin{array}{l}\text { 軽い副作 } \\
\text { 用で継続 }\end{array}$ & $\begin{array}{l}\text { 副作用の } \\
\text { ため中止 }\end{array}$ & & & & & \\
\hline \multirow{2}{*}{ 第 1 治療期 } & F P & 102 & 0 & 3 & 4 & 109 & 3 & \multirow{2}{*}{$\mathrm{NS}$} & \multirow{2}{*}{ N S } \\
\hline & $\mathrm{P}$ & 97 & 0 & 1 & 3 & 101 & 1 & & \\
\hline \multirow{2}{*}{ 第 2 治療期 } & F P & 78 & 0 & 0 & 12 & 90 & 0 & \multirow{2}{*}{$\begin{array}{c}\mathrm{F} \mathrm{P}>\mathrm{P} \\
*\end{array}$} & \multirow{2}{*}{$\underset{*}{\mathrm{~F}} \underset{ }{\mathrm{P}}>\mathrm{P}$} \\
\hline & $\mathrm{P}$ & 91 & 5 & 0 & 4 & 100 & 5 & & \\
\hline
\end{tabular}

表 8 副作用

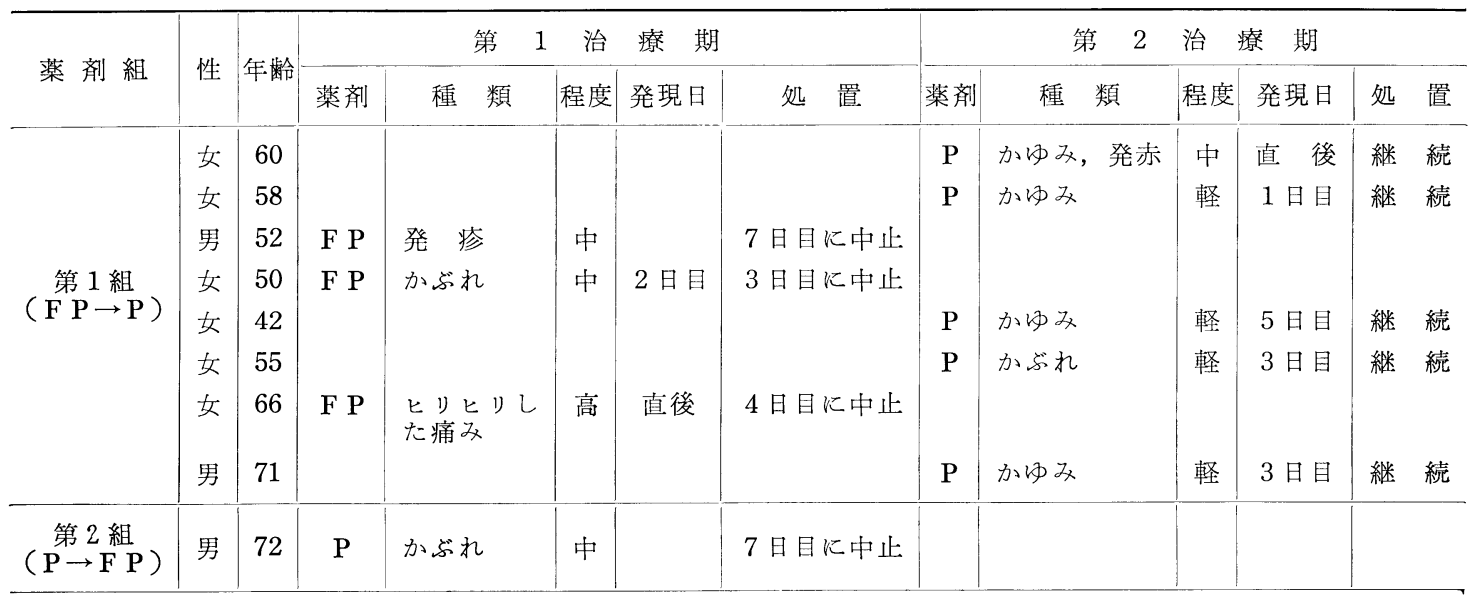


1）群間比較

表 9 全般有用度

\begin{tabular}{|c|c|c|c|c|c|c|c|c|c|c|c|c|c|c|c|}
\hline 治 & 薬 & \multicolumn{6}{|c|}{ 全 般有 用 度 } & & 脱 & \multirow{3}{*}{ 計 } & \multicolumn{4}{|c|}{$\chi^{2}$ test } & \multirow{3}{*}{$U$ test } \\
\hline 療 & & きて & 有 & や有 & 有な & や有 & 有 & きて & \multirow[b]{2}{*}{ 落 } & & & 有 用 & $\geqq や$ & 有用 & \\
\hline 期 & 剤 & め用 & 用 & や用 & 性 乙 & や害 & 害 & め害 & & & $\%$ & & $\%$ & & \\
\hline 第治 & F P & 3 & 28 & 47 & 22 & 0 & 0 & 0 & 9 & 109 & 28 & $\mathrm{FP}>\mathrm{P}$ & 72 & & $F P>P$ \\
\hline 1 期 & $\mathrm{P}$ & 3 & 14 & 47 & 27 & 1 & 0 & 0 & 9 & 101 & 17 & & 63 & & \\
\hline 第治 & F P & 4 & 26 & 32 & 13 & 0 & 0 & 0 & 15 & 90 & 33 & NTS & 69 & $N_{T}$ & $F P>P$ \\
\hline 2 期 & $\mathrm{P}$ & 0 & 27 & 44 & 22 & 2 & 0 & 0 & 5 & 100 & 27 & & 71 & & \\
\hline
\end{tabular}

2 ）患者内薬剂比較

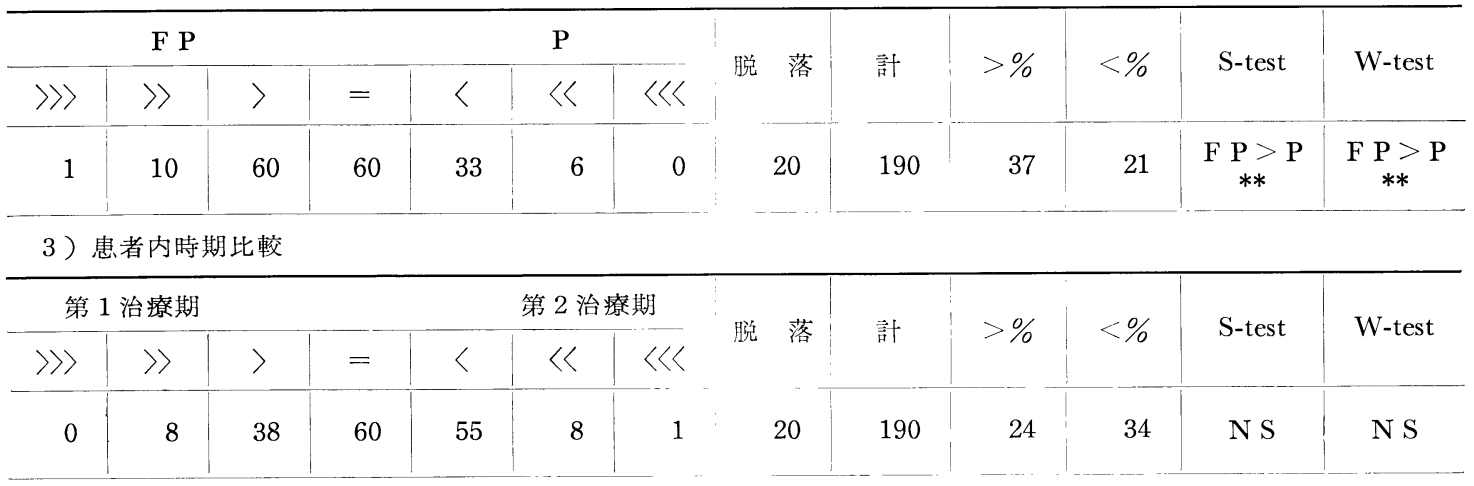

1) 群間比較

表 10 全般有用度（主治医判定）

\begin{tabular}{|c|c|c|c|c|c|c|c|c|c|c|c|c|c|c|c|}
\hline \multirow{3}{*}{$\begin{array}{l}\text { 治 } \\
\text { 療 } \\
\text { 期 }\end{array}$} & \multirow{3}{*}{$\begin{array}{l}\text { 薬 } \\
\text { 剂 }\end{array}$} & \multicolumn{6}{|c|}{ 全 般 有 用 度 } & & 脱 & \multirow{3}{*}{ 計 } & \multicolumn{4}{|c|}{$\chi^{2}$ test } & \multirow{3}{*}{$\mathrm{U}$ test } \\
\hline & & きて & 有 & や有 & 有な & や有 & 有 & 昰 & \multirow[b]{2}{*}{ 落 } & & \multicolumn{2}{|c|}{ ミ有 用 } & \multicolumn{2}{|c|}{ ミやや有用 } & \\
\hline & & め用 & 用 & や用 & 性乙 & や害 & 害 & め害 & & & $\%$ & & $\%$ & & \\
\hline \multirow{2}{*}{$\begin{array}{r}\text { 第治 } \\
\text { 療 } \\
1 \text { 期 }\end{array}$} & F P & 3 & 29 & 47 & 22 & 0 & 0 & 0 & 8 & 109 & 29 & \multirow{2}{*}{ N S } & 72 & \multirow{2}{*}{ N S } & $F P>P$ \\
\hline & $\mathrm{P}$ & 4 & 15 & 48 & 27 & 1 & 0 & 0 & 6 & 101 & 19 & & 66 & & \\
\hline \multirow{2}{*}{$\begin{array}{r}\text { 第治 } \\
\text { 療 } \\
2 \text { 期 }\end{array}$} & F P & 4 & 29 & 32 & 13 & 0 & 0 & 0 & 12 & 90 & 37 & \multirow{2}{*}{ N S } & 72 & \multirow{2}{*}{ N S } & \multirow{2}{*}{$\underset{*}{\mathrm{~F} \mathrm{P}}>\mathrm{P}$} \\
\hline & $P$ & 1 & 27 & 44 & 22 & 2 & 0 & 0 & 4 & 100 & 28 & & 72 & & \\
\hline
\end{tabular}

2）患者内薬鼡比較

\begin{tabular}{|c|c|c|c|c|c|c|c|c|c|c|c|c|}
\hline \multicolumn{4}{|c|}{ F P } & \multicolumn{3}{|c|}{$\mathrm{P}$} & \multirow{2}{*}{ 脱 落 } & \multirow{2}{*}{ 計 } & \multirow{2}{*}{$>\%$} & \multirow{2}{*}{$<\%$} & \multirow{2}{*}{ S-test } & \multirow{2}{*}{$\mathrm{W}$-test } \\
\hline$\gg \gg$ & $\gg$ & $>$ & $=$ & $<$ & $\ll$ & $\ll<$ & & & & & & \\
\hline 1 & 10 & 61 & 61 & 35 & 6 & 0 & 16 & 190 & 38 & 22 & $\underset{* *}{\mathrm{~F}} \mathrm{P}>\mathrm{P}$ & $\underset{* *}{\mathrm{~F}} \mathrm{P}>\mathrm{P}$ \\
\hline
\end{tabular}

3 ）患者内時期比較

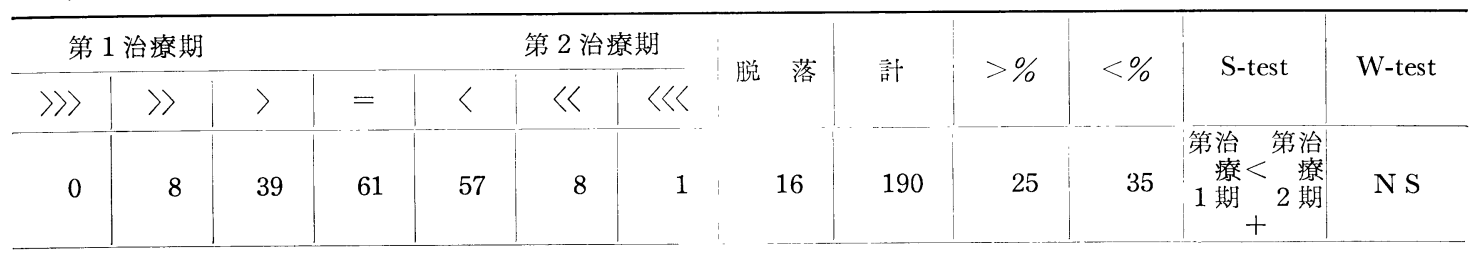


1 ) 薬剤比較

表 11 医師の優劣判定

\begin{tabular}{|c|c|c|c|c|c|c|c|c|c|c|c|c|}
\hline \multicolumn{3}{|c|}{ F P } & \multicolumn{2}{|c|}{$>=<$} & \multicolumn{2}{|l|}{$\mathbf{P}$} & \multirow[b]{2}{*}{ 脱 落 } & \multirow[b]{2}{*}{ 合 計 } & \multirow[b]{2}{*}{$>\%$} & \multirow[b]{2}{*}{$<\%$} & \multirow[b]{2}{*}{ S-test } & \multirow[b]{2}{*}{$\mathrm{W}$-test } \\
\hline $\begin{array}{l}\text { 非有 } \\
\text { 常 } \\
\text { に用 }\end{array}$ & $\begin{array}{l}\text { 有 } \\
\text { 用 }\end{array}$ & $\begin{array}{l}\text { や有 } \\
\text { や用 }\end{array}$ & $\begin{array}{lll}\text { ど } & \text { え } \\
ち & も な \\
ら & \text { いい }\end{array}$ & $\begin{array}{l}\text { や有 } \\
\text { や用 }\end{array}$ & $\begin{array}{l}\text { 有 } \\
\text { 用 }\end{array}$ & $\begin{array}{l}\text { 非有 } \\
\text { 常用 } \\
\text { に用 }\end{array}$ & & & & & & \\
\hline 5 & 30 & 42 & 48 & 24 & 21 & 0 & 20 & 190 & 41 & 24 & $\underset{* *}{\mathrm{~F}} \underset{ }{\mathrm{P}>\mathrm{P}}$ & $\underset{* *}{\mathrm{~F}} \mathrm{P}>\mathrm{P}$ \\
\hline
\end{tabular}

2 ) 時期比較

\begin{tabular}{|c|c|c|c|c|c|c|c|c|c|c|c|c|}
\hline \multicolumn{3}{|c|}{ 第 1 治療期 } & \multirow{2}{*}{$\begin{array}{l}>=< \\
\text { どをえ } \\
\text { ちむな } \\
\text { らいい }\end{array}$} & \multicolumn{3}{|c|}{ 第 2 治療期 } & \multirow[b]{2}{*}{ 脱 落 } & \multirow[b]{2}{*}{ 合 計 } & \multirow[b]{2}{*}{$>\%$} & \multirow[b]{2}{*}{$<\%$} & \multirow[b]{2}{*}{ S-test } & \multirow[b]{2}{*}{$\mathrm{W}$-test } \\
\hline $\begin{array}{l}\text { 非有 } \\
\text { 常用 }\end{array}$ & $\begin{array}{l}\text { 有 } \\
\text { 用 }\end{array}$ & $\begin{array}{l}\text { や有 } \\
\text { や用 }\end{array}$ & & $\begin{array}{l}\text { や有 } \\
\text { や用 }\end{array}$ & $\begin{array}{l}\text { 有 } \\
\text { 用 }\end{array}$ & $\begin{array}{l}\text { 非有 } \\
\text { 常 } \\
\text { 江用 }\end{array}$ & & & & & & \\
\hline 2 & 23 & 23 & 48 & 43 & 28 & 3 & 20 & 190 & 25 & 39 & $\begin{array}{c}\text { 第 } 1 \text { 第 } 2 \\
\text { 治療期 } \\
*\end{array}$ & N S \\
\hline
\end{tabular}

1) 薬剤比較

表 12 医師の優劣判定（主治医判定）

\begin{tabular}{|c|c|c|c|c|c|c|c|c|c|c|c|c|}
\hline \multicolumn{3}{|c|}{ F P } & \multicolumn{2}{|c|}{$>=<$} & \multicolumn{2}{|c|}{$\mathrm{P}$} & \multirow[b]{2}{*}{ 脱 落 } & \multirow[b]{2}{*}{ 合 計 } & \multirow[b]{2}{*}{$>\%$} & \multirow[b]{2}{*}{$<\%$} & \multirow[b]{2}{*}{ S-test } & \multirow[b]{2}{*}{$\mathrm{W}$-test } \\
\hline $\begin{array}{l}\text { 非有 } \\
\text { 常 } \\
\text { に用 }\end{array}$ & $\begin{array}{l}\text { 有 } \\
\text { 用 }\end{array}$ & $\begin{array}{l}\text { や有 } \\
\text { や用 }\end{array}$ & 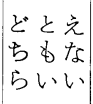 & $\begin{array}{l}\text { や有 } \\
\text { や用 }\end{array}$ & $\begin{array}{l}\text { 有 } \\
\text { 用 }\end{array}$ & $\begin{array}{l}\text { 非有 } \\
\text { 常 } \\
\text { に用 }\end{array}$ & & & & & & \\
\hline 5 & 31 & 42 & 51 & 24 & 21 & 0 & 16 & 190 & 41 & 24 & $\underset{* *}{\mathrm{~F}} \mathrm{P}>\mathrm{P}$ & $\underset{* *}{\mathrm{~F}} \mathrm{P}>\mathrm{P}$ \\
\hline
\end{tabular}

2 ）時期比較

\begin{tabular}{|c|c|c|c|c|c|c|c|c|c|c|c|c|}
\hline \multicolumn{3}{|c|}{ 第 1 治療期 } & \multirow{2}{*}{ 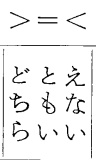 } & \multicolumn{3}{|c|}{ 第 2 治療期 } & \multirow[b]{2}{*}{ 脱 落 } & \multirow[b]{2}{*}{ 合 計 } & \multirow[b]{2}{*}{$>\%$} & \multirow[b]{2}{*}{$<\%$} & \multirow[b]{2}{*}{ S-test } & \multirow[b]{2}{*}{$\mathrm{W}$-test } \\
\hline $\begin{array}{l}\text { 非有 } \\
\text { 常 } \\
\text { 江用 }\end{array}$ & $\begin{array}{l}\text { 有 } \\
\text { 用 }\end{array}$ & $\begin{array}{l}\text { や有 } \\
\text { や用 }\end{array}$ & & $\begin{array}{l}\text { や有 } \\
\text { や用 }\end{array}$ & $\begin{array}{l}\text { 有 } \\
\text { 用 }\end{array}$ & $\begin{array}{l}\text { 非有 } \\
\text { 常 } \\
\text { に用 }\end{array}$ & & & & & & \\
\hline 2 & 23 & 23 & 51 & 43 & 29 & 3 & 16 & 190 & 25 & 39 & $\begin{array}{c}\text { 第 } 1 \\
\text { 治療期 } \\
*\end{array}$ & $\begin{array}{c}\text { 第 } 1 \\
\text { 治療期 } \\
+ \\
+\end{array}$ \\
\hline
\end{tabular}

除外・脱落を決定した。また，これとは別に主治医判定 として主治医が決定した除外・脱落も重視して，解析を 行った.

\section{（8）データの固定と解析}

除外・脱落を決定したのち, 全データをコンピュータ ーに入力し，データを固定した.

解析はコントローラー委員会の薬効評価システム（ク ロスオーバー法) $)^{7)}$ にって行った。 統計手法はデータ の尺度に応じて Mann-Whitney U test (以下 U test), $\chi^{2}$ test, Wilcoxon matched-pairs signed-ranks test (以 下 W-test), sign test（以下 S-test）であり，有意水準は 原則として両側 $5 \%$ とした。

解析結果はつぎの略号を用いて表示した.

$\mathrm{N} \mathrm{S} ; \mathrm{P}>0.01,+$; $\mathrm{P} \leqq 0.1, * ; \mathrm{P} \leqq 0.05, * *$; $\mathrm{P} \leqq 0.01, * * * ; \mathrm{P} \leqq 0.001$

なお，除外例はすべての解析より除外し，脱落例は解
析上，無効例として扱い，概括安全度に拈ける脱落例で は副作用なしとして扱った。

\section{結 果}

結果は世話人会に打いて協議した中央判定を中心に示 したが，全般有用度と医師の優劣判定については主治医 判定も示した.

(1) 対象症例

総症例数は221例で, 第 1 組「F P $\rightarrow \mathrm{P} 」 112$ 例, 第 2 組「P $\rightarrow$ F P」109例であった.

解析対象例数は表 2 のごとくであった。

な打除外例の詳細を表 3 に, 脱落例の詳細を表 4 に示 した.

(2) 背景因子

総症例 221 例の背景因子（性, 年龄, 入院 - 外来, 疾 患分類, 重症度, 現病歴, 合併症, 貼付部位, 併用薬な 
1）群間比較

表 13 患者の総合評価

\begin{tabular}{|c|c|c|c|c|c|c|c|c|c|c|c|c|c|}
\hline \multirow{3}{*}{ 治 療 期 } & \multirow{3}{*}{ 薬 剤 } & \multicolumn{5}{|c|}{ 患者の総合評価 } & 脱 & 合 & \multicolumn{4}{|c|}{$\chi^{2}$ test } & \multirow{3}{*}{$\mathrm{U}$ test } \\
\hline & & 改 & や改 & 不 & や悪 & 悪 & & & $\geqq$ & 善 & & や改善 & \\
\hline & & 善 & や善 & 変 & や化 & 化 & 落 & 計 & $\%$ & & $\%$ & & \\
\hline \multirow{2}{*}{ 第 1 治療期 } & F P & 18 & 59 & 22 & 3 & 0 & 7 & 109 & 17 & \multirow{2}{*}{ N S } & 71 & \multirow{2}{*}{$\begin{array}{c}\mathrm{F} \mathrm{P}>\mathrm{P} \\
+\end{array}$} & \multirow{2}{*}{$\begin{array}{c}\mathrm{F} \mathrm{P}>\mathrm{P} \\
*\end{array}$} \\
\hline & $\mathrm{P}$ & 10 & 48 & 31 & 5 & 1 & 6 & 101 & 10 & & 57 & & \\
\hline \multirow{2}{*}{ 第 2 治療期 } & F P & 17 & 43 & 14 & 1 & 0 & 15 & 90 & 19 & \multirow{2}{*}{ N S } & 67 & \multirow{2}{*}{ N S } & \multirow{2}{*}{$\begin{array}{c}\mathrm{F} \mathrm{P}>\mathrm{P} \\
+\end{array}$} \\
\hline & $\mathbf{P}$ & 11 & 53 & 26 & 4 & 1 & 5 & 100 & 11 & & 64 & & \\
\hline
\end{tabular}

2 ）患者内薬剤比較

\begin{tabular}{|c|c|c|c|c|c|c|c|c|c|c|c|c|}
\hline \multicolumn{4}{|c|}{ F P } & \multicolumn{2}{|r|}{$\mathrm{P}$} & & \multirow{2}{*}{ 脱 } & \multirow{2}{*}{ 合 計 } & \multirow{2}{*}{$>\%$} & \multirow{2}{*}{$<\%$} & \multirow{2}{*}{ S-test } & \multirow{2}{*}{$\mathrm{W}$-test } \\
\hline$\gg \gg$ & $\gg$ & $>$ & $=$ & $<$ & $\ll$ & $\ll<$ & & & & & & \\
\hline 1 & 7 & 46 & 93 & 22 & 1 & 0 & 20 & 190 & 28 & 12 & $\underset{* * *}{\mathrm{~F}} \underset{ }{\mathrm{P}}>\mathrm{P}$ & $\underset{* * *}{\mathrm{~F}} \underset{\mathrm{P}}{\mathrm{P}}>\mathrm{P}$ \\
\hline
\end{tabular}

3）患者内時期比較

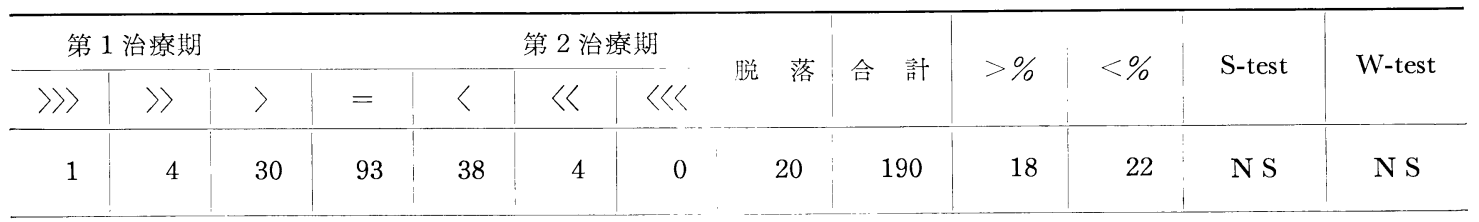

1) 藤剤比較

表 14 患者の優劣判定

\begin{tabular}{|c|c|c|c|c|c|c|c|c|c|c|c|}
\hline \multicolumn{2}{|c|}{ F P } & \multicolumn{2}{|l|}{$>=<$} & $P$ & \multirow[b]{2}{*}{ 脱 } & \multirow[b]{2}{*}{ 落 } & \multirow[b]{2}{*}{ 竐 } & \multirow[b]{2}{*}{$>\%$} & \multirow[b]{2}{*}{$<\%$} & \multirow[b]{2}{*}{ S-test } & \multirow[b]{2}{*}{$\mathrm{W}$-test } \\
\hline $\begin{array}{l}\text { 優い } \\
\text { れる } \\
\text { て }\end{array}$ & $\begin{array}{l}\text { やれる } \\
\text { やて } \\
\text { 優い }\end{array}$ & 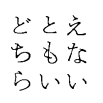 & $\begin{array}{l}\text { やれる } \\
\text { やて } \\
\text { 優い }\end{array}$ & $\begin{array}{l}\text { 優い } \\
\text { れる } \\
\text { て }\end{array}$ & & & & & & & \\
\hline 22 & 47 & 65 & 24 & 12 & & 20 & 190 & 36 & 19 & $\underset{* *}{\mathrm{~F}} \underset{ }{\mathrm{P}}>\mathrm{P}$ & $F P>P$ \\
\hline
\end{tabular}

2) 時期比較

\begin{tabular}{|c|c|c|c|c|c|c|c|c|c|c|}
\hline \multicolumn{2}{|c|}{ 第 1 治療期 } & \multirow{2}{*}{$\begin{array}{l}>=< \\
\text { ぞとえ } \\
\text { ちむな } \\
\text { らいい }\end{array}$} & \multicolumn{2}{|c|}{ 第 2 治療期 } & \multirow[b]{2}{*}{ 脱 落 } & \multirow[b]{2}{*}{ 計 } & \multirow[b]{2}{*}{$>\%$} & \multirow[b]{2}{*}{$<\%$} & \multirow[b]{2}{*}{ S-test } & \multirow[b]{2}{*}{$\mathrm{W}$-test } \\
\hline $\begin{array}{l}\text { 優い } \\
\text { 机る } \\
\text { て }\end{array}$ & $\begin{array}{l}\text { やれる } \\
\text { やて } \\
\text { 優い }\end{array}$ & & $\begin{array}{l}\text { やれる } \\
\text { やて } \\
\text { 優い }\end{array}$ & $\begin{array}{l}\text { 優い } \\
\text { れる } \\
\text { て }\end{array}$ & & & & & & \\
\hline 6 & 27 & 65 & 44 & 18 & 20 & 190 & 23 & 33 & $\begin{array}{c}\text { 第 } 1 \\
\text { 治療期 } \\
{ }^{+} \\
+\end{array}$ & $\mathrm{NS}$ \\
\hline
\end{tabular}

ど）について検討した結果，表 5 のごとく，いずれの項 目に括いても第 1 組と第 2 組との間に偏りはみられなか った。

(3) 全般改善度

全般改善度の結果を表 6 に示した。

群間比較では第 1 期，第 2 期ともに FP 群 P が P 群よ

りも改善する傾向にあった。

患者内薬剤比較 (190例) では FP が P よりも有意に
優った（S-test, W-test).

患者内時期比較では第 2 期が 有意に優った（S-test, W-test).

(4) 概括安全度

概括安全度は，表 7 に示すごとく，第 1 期では有意差 はみられなかったが，第 2 期では FP 群が有意に安全性 が高かった（ $\chi^{2}$ test, U test).

副作用は，第 1 期では FP 群 3 例 ( $3 \%), \quad \mathrm{P}$ 群 1 例 
表 15 症状別重症度の分布（群間比較）

\begin{tabular}{|c|c|c|c|c|c|c|c|c|c|}
\hline \multirow{2}{*}{ 症状項目 } & \multirow{2}{*}{ 治 療 期 } & \multirow{2}{*}{ 薬 剂 } & \multicolumn{4}{|c|}{ 症 状 重症度 } & \multirow{2}{*}{ 脱 落 } & \multirow{2}{*}{ 合 計 } & \multirow{2}{*}{$\mathrm{U}$ test } \\
\hline & & & 症状なし & 軽 度 & 中等度 & 高 度 & & & \\
\hline \multirow{3}{*}{ 自 発 痛 } & 治療開始時 & $\underset{P}{\mathrm{~F} P}$ & $\begin{array}{l}2 \\
0\end{array}$ & $\begin{array}{l}43 \\
51\end{array}$ & $\begin{array}{l}31 \\
20\end{array}$ & $\begin{array}{l}2 \\
1\end{array}$ & $\begin{array}{l}0 \\
0\end{array}$ & $\begin{array}{l}78 \\
72\end{array}$ & N S \\
\hline & 第 1 治療期 & $\underset{P}{\text { F P }}$ & $\begin{array}{l}25 \\
10\end{array}$ & $\begin{array}{l}42 \\
48\end{array}$ & $\begin{array}{l}6 \\
8\end{array}$ & $\begin{array}{l}1 \\
1\end{array}$ & $\begin{array}{l}4 \\
5\end{array}$ & $\begin{array}{l}78 \\
72\end{array}$ & $\underset{*}{\mathrm{~F} \mathrm{P}>\mathrm{P}}$ \\
\hline & 第 2 治療期 & $\underset{\mathrm{P}}{\mathrm{F} P}$ & $\begin{array}{l}24 \\
26\end{array}$ & $\begin{array}{l}24 \\
35\end{array}$ & $\begin{array}{l}5 \\
8\end{array}$ & $\begin{array}{l}0 \\
1\end{array}$ & $\begin{array}{r}11 \\
2\end{array}$ & $\begin{array}{l}64 \\
72\end{array}$ & N S \\
\hline \multirow{3}{*}{ 痛 } & 治療開始時 & $\underset{P}{\text { F P }}$ & $\begin{array}{l}0 \\
1\end{array}$ & $\begin{array}{l}37 \\
35\end{array}$ & $\begin{array}{l}56 \\
52\end{array}$ & $\begin{array}{r}10 \\
7\end{array}$ & $\begin{array}{l}0 \\
0\end{array}$ & $\begin{array}{r}103 \\
95\end{array}$ & N S \\
\hline & 第 1 治療期 & $\underset{P}{F P}$ & $\begin{array}{l}7 \\
5\end{array}$ & $\begin{array}{l}59 \\
59\end{array}$ & $\begin{array}{l}29 \\
21\end{array}$ & $\begin{array}{l}2 \\
5\end{array}$ & $\begin{array}{l}6 \\
5\end{array}$ & $\begin{array}{r}103 \\
95\end{array}$ & N S \\
\hline & 第 2 治療期 & $\underset{\mathrm{P}}{\mathrm{F}}$ & $\begin{array}{r}15 \\
9\end{array}$ & $\begin{array}{l}43 \\
58\end{array}$ & $\begin{array}{l}11 \\
21\end{array}$ & $\begin{array}{l}1 \\
2\end{array}$ & $\begin{array}{r}15 \\
5\end{array}$ & $\begin{array}{l}85 \\
95\end{array}$ & $\begin{array}{c}\mathrm{F} \mathrm{P}>\mathrm{P} \\
*\end{array}$ \\
\hline \multirow{3}{*}{ 運 動 痛 } & 治療開始時 & $\begin{array}{c}\mathrm{F} P \\
\mathrm{P}\end{array}$ & $\begin{array}{l}0 \\
1\end{array}$ & $\begin{array}{l}27 \\
29\end{array}$ & $\begin{array}{l}65 \\
61\end{array}$ & $\begin{array}{r}12 \\
6\end{array}$ & $\begin{array}{l}0 \\
0\end{array}$ & $\begin{array}{r}104 \\
97\end{array}$ & N S \\
\hline & 第 1 治療期 & $\underset{P}{\mathrm{~F} P}$ & $\begin{array}{l}5 \\
8\end{array}$ & $\begin{array}{l}62 \\
55\end{array}$ & $\begin{array}{l}25 \\
24\end{array}$ & $\begin{array}{l}6 \\
5\end{array}$ & $\begin{array}{l}6 \\
5\end{array}$ & $\begin{array}{r}104 \\
97\end{array}$ & N S \\
\hline & 第 2 治療期 & $\underset{P}{\mathrm{~F} P}$ & $\begin{array}{l}16 \\
10\end{array}$ & $\begin{array}{l}44 \\
59\end{array}$ & $\begin{array}{l}11 \\
18\end{array}$ & $\begin{array}{l}1 \\
5\end{array}$ & $\begin{array}{r}15 \\
5\end{array}$ & $\begin{array}{l}87 \\
97\end{array}$ & $\underset{*}{\mathrm{~F} \mathrm{P}>\mathrm{P}}$ \\
\hline \multirow{3}{*}{ 局 所 熱 感 } & 治療開始時 & ${ }_{\mathrm{P} P}$ & $\begin{array}{l}0 \\
0\end{array}$ & $\begin{array}{l}23 \\
22\end{array}$ & $\begin{array}{l}7 \\
6\end{array}$ & $\begin{array}{l}1 \\
0\end{array}$ & $\begin{array}{l}0 \\
0\end{array}$ & $\begin{array}{l}31 \\
28\end{array}$ & N S \\
\hline & 第 1 治療期 & $\underset{P}{\mathrm{~F} P}$ & $\begin{array}{l}8 \\
7\end{array}$ & $\begin{array}{l}21 \\
16\end{array}$ & $\begin{array}{l}1 \\
4\end{array}$ & $\begin{array}{l}0 \\
0\end{array}$ & $\begin{array}{l}1 \\
1\end{array}$ & $\begin{array}{l}31 \\
28\end{array}$ & N S \\
\hline & & $\underset{\mathbf{P}}{\mathrm{F} P}$ & $\begin{array}{r}9 \\
12\end{array}$ & $\begin{array}{l}10 \\
14\end{array}$ & $\begin{array}{l}1 \\
2\end{array}$ & $\begin{array}{l}0 \\
0\end{array}$ & $\begin{array}{l}6 \\
1\end{array}$ & $\begin{array}{l}26 \\
29\end{array}$ & $\mathrm{~N} \mathrm{~S}$ \\
\hline \multirow{3}{*}{ 腫 } & 治療開始時 & $\underset{\mathrm{P}}{\mathrm{F} P}$ & $\begin{array}{l}0 \\
0\end{array}$ & $\begin{array}{l}36 \\
27\end{array}$ & $\begin{array}{r}15 \\
8\end{array}$ & $\begin{array}{l}1 \\
1\end{array}$ & $\begin{array}{l}0 \\
0\end{array}$ & $\begin{array}{l}52 \\
36\end{array}$ & N S \\
\hline & 第 1 治療期 & $\underset{\mathrm{P}}{\mathrm{F} P}$ & $\begin{array}{l}8 \\
4\end{array}$ & $\begin{array}{l}36 \\
26\end{array}$ & $\begin{array}{l}7 \\
5\end{array}$ & $\begin{array}{l}0 \\
0\end{array}$ & $\begin{array}{l}1 \\
1\end{array}$ & $\begin{array}{l}52 \\
36\end{array}$ & N S \\
\hline & 第 2 治療期 & $\underset{P}{\mathrm{~F} P}$ & $\begin{array}{r}4 \\
16\end{array}$ & $\begin{array}{l}18 \\
25\end{array}$ & $\begin{array}{l}4 \\
5\end{array}$ & $\begin{array}{l}0 \\
0\end{array}$ & $\begin{array}{l}8 \\
1\end{array}$ & $\begin{array}{l}34 \\
47\end{array}$ & N S \\
\hline \multirow{3}{*}{ 運 動 制 限 } & 治療開始時 & $\begin{array}{l}\text { F P } \\
\text { P }\end{array}$ & $\begin{array}{l}1 \\
0\end{array}$ & $\begin{array}{l}35 \\
33\end{array}$ & $\begin{array}{l}28 \\
30\end{array}$ & $\begin{array}{l}6 \\
3\end{array}$ & $\begin{array}{l}0 \\
0\end{array}$ & $\begin{array}{l}70 \\
66\end{array}$ & N S \\
\hline & 第 1 治療期 & $\underset{P}{F P}$ & $\begin{array}{l}8 \\
6\end{array}$ & $\begin{array}{l}39 \\
34\end{array}$ & $\begin{array}{l}15 \\
21\end{array}$ & $\begin{array}{l}4 \\
3\end{array}$ & $\begin{array}{l}4 \\
2\end{array}$ & $\begin{array}{l}70 \\
66\end{array}$ & N S \\
\hline & 第 2 治療期 & $\underset{P}{F P}$ & $\begin{array}{r}11 \\
9\end{array}$ & $\begin{array}{l}30 \\
39\end{array}$ & $\begin{array}{l}10 \\
12\end{array}$ & $\begin{array}{l}1 \\
2\end{array}$ & $\begin{array}{l}9 \\
2\end{array}$ & $\begin{array}{l}61 \\
64\end{array}$ & N S \\
\hline \multirow{3}{*}{ 筋 緊 張 } & 治療開始時 & $\begin{array}{l}\text { F P } \\
P\end{array}$ & $\begin{array}{l}4 \\
0\end{array}$ & $\begin{array}{l}44 \\
47\end{array}$ & $\begin{array}{l}20 \\
11\end{array}$ & $\begin{array}{l}4 \\
1\end{array}$ & $\begin{array}{l}0 \\
0\end{array}$ & $\begin{array}{l}72 \\
59\end{array}$ & N S \\
\hline & 第 1 治療期 & $\underset{\mathrm{P}}{\mathrm{F} P}$ & $\begin{array}{l}16 \\
13\end{array}$ & $\begin{array}{l}43 \\
35\end{array}$ & $\begin{array}{l}7 \\
8\end{array}$ & $\begin{array}{l}3 \\
1\end{array}$ & $\begin{array}{l}3 \\
2\end{array}$ & $\begin{array}{l}72 \\
59\end{array}$ & N S \\
\hline & 第 2 治療期 & $\underset{\mathrm{P}}{\mathrm{FP}}$ & $\begin{array}{l}16 \\
26\end{array}$ & $\begin{array}{l}28 \\
30\end{array}$ & $\begin{array}{l}3 \\
8\end{array}$ & $\begin{array}{l}0 \\
1\end{array}$ & $\begin{array}{l}7 \\
2\end{array}$ & $\begin{array}{l}54 \\
67\end{array}$ & N S \\
\hline
\end{tabular}

( $1 \%$ ) 発現し，第 2 期では FP 群に副作用はまったく なく、P群に 5 例 $(5 \%)$ 発現した. 副作用の種類は表 8 のごとく，いずれも局所の皮膚刺激症状であった.

(5) 全般有用度

全般有用度の結果を表 9 に示した。

群間比較では第 1 期において FP 群が有意に優り（U test)，第 2 期においては FP 群が優る傾向にあった。

患者内薬剤比較では FP が有意に優った（S-test，Wtest).
患者内時期比較では第 1 期と第 2 期との間に有意差は みられなかった。

主治医判定による全般有用度の結果を表10に示した。 群間比較では第 1 期に括いて FP 群が優る 傾向にあ り，第 2 期においてはFP 群が有意に優った (U test).

患者内薬剂比較, 患者内時期比較では中央判定での結 果と同様であった.

(6) 医師の優劣判定

医師の優劣判定の結果を表11に示した. 
表 16 症状別重症度の変化（群間比較）

\begin{tabular}{|c|c|c|c|c|c|c|c|c|c|c|c|c|c|c|}
\hline \multirow{2}{*}{ 症状項目 } & \multirow{2}{*}{ 治 療 期 } & \multirow{2}{*}{ 薬剤 } & \multicolumn{3}{|c|}{ 改 善 } & \multirow{2}{*}{$\begin{array}{c}\text { 変化 } \\
\text { な } \\
0 \\
0\end{array}$} & \multicolumn{3}{|c|}{ 悪 化 } & \multirow{2}{*}{ 脱落 } & \multirow{2}{*}{ 合計 } & \multirow{2}{*}{$\left|\begin{array}{cc}\text { 症 } & \text { 症 } \\
\text { 状 } & \text { 状 } \\
\text { な } & \text { な } \\
\text { し } & \text { し }\end{array}\right|$} & \multicolumn{2}{|l|}{ 改 } \\
\hline & & & -3 & -2 & -1 & & +1 & +2 & +3 & & & & $(\%)$ & $\chi^{2}$ test \\
\hline \multirow{2}{*}{ 自 発 痛 } & 第 1 治療期 & $\underset{P}{F}$ & $\begin{array}{l}0 \\
0\end{array}$ & $\begin{array}{l}5 \\
2\end{array}$ & $\begin{array}{l}39 \\
20\end{array}$ & $\begin{array}{l}29 \\
42\end{array}$ & $\begin{array}{l}1 \\
3\end{array}$ & $\begin{array}{l}0 \\
0\end{array}$ & $\begin{array}{l}0 \\
0\end{array}$ & $\begin{array}{l}4 \\
5\end{array}$ & $\begin{array}{l}78 \\
72\end{array}$ & \begin{tabular}{l|}
31 \\
29
\end{tabular} & $\begin{array}{l}56 \\
31\end{array}$ & $\underset{* *}{\mathrm{~F}} \mathrm{P}>\mathrm{P}$ \\
\hline & 第 2 治療期 & $\begin{array}{l}\text { F P } \\
P\end{array}$ & $\begin{array}{l}0 \\
0\end{array}$ & $\begin{array}{l}3 \\
5\end{array}$ & $\begin{array}{l}31 \\
37\end{array}$ & $\begin{array}{l}19 \\
26\end{array}$ & $\begin{array}{l}0 \\
2\end{array}$ & $\begin{array}{l}0 \\
0\end{array}$ & $\begin{array}{l}0 \\
0\end{array}$ & $\begin{array}{r}11 \\
2\end{array}$ & $\begin{array}{l}64 \\
72\end{array}$ & $\begin{array}{l}26 \\
28\end{array}$ & $\begin{array}{l}53 \\
58\end{array}$ & N S \\
\hline \multirow{2}{*}{ 圧 痛 } & 第 1 治療期 & $\underset{P}{\text { F P }}$ & $\begin{array}{l}0 \\
0\end{array}$ & $\begin{array}{l}5 \\
1\end{array}$ & $\begin{array}{l}38 \\
36\end{array}$ & $\begin{array}{l}52 \\
52\end{array}$ & $\begin{array}{l}2 \\
1\end{array}$ & $\begin{array}{l}0 \\
0\end{array}$ & $\begin{array}{l}0 \\
0\end{array}$ & $\begin{array}{l}6 \\
5\end{array}$ & $\begin{array}{r}103 \\
95\end{array}$ & $\begin{array}{l}6 \\
6\end{array}$ & $\begin{array}{l}42 \\
39\end{array}$ & $\mathrm{NS}$ \\
\hline & 第 2 治療期 & ${ }_{\mathrm{P} P}$ & $\begin{array}{l}0 \\
0\end{array}$ & $\begin{array}{l}5 \\
7\end{array}$ & $\begin{array}{l}40 \\
37\end{array}$ & $\begin{array}{l}24 \\
45\end{array}$ & $\begin{array}{l}1 \\
1\end{array}$ & $\begin{array}{l}0 \\
0\end{array}$ & $\begin{array}{l}0 \\
0\end{array}$ & $\begin{array}{r}15 \\
5\end{array}$ & $\begin{array}{l}85 \\
95\end{array}$ & $\begin{array}{l}5 \\
5\end{array}$ & $\begin{array}{l}53 \\
46\end{array}$ & N S \\
\hline \multirow{2}{*}{ 運 動 痛 } & 第 1 治療期 & $\underset{\mathrm{P}}{\mathrm{FP}}$ & $\begin{array}{l}0 \\
0\end{array}$ & $\begin{array}{l}6 \\
1\end{array}$ & $\begin{array}{l}41 \\
43\end{array}$ & $\begin{array}{l}49 \\
47\end{array}$ & $\begin{array}{l}2 \\
1\end{array}$ & $\begin{array}{l}0 \\
0\end{array}$ & $\begin{array}{l}0 \\
0\end{array}$ & $\begin{array}{l}6 \\
5\end{array}$ & $\begin{array}{r}104 \\
97\end{array}$ & $\begin{array}{l}5 \\
4\end{array}$ & $\begin{array}{l}45 \\
45\end{array}$ & N S \\
\hline & 第 2 治療期 & $\begin{array}{c}\mathrm{FP} P \\
\mathrm{P}\end{array}$ & $\begin{array}{l}0 \\
1\end{array}$ & $\begin{array}{l}9 \\
4\end{array}$ & $\begin{array}{l}39 \\
50\end{array}$ & $\begin{array}{l}24 \\
35\end{array}$ & $\begin{array}{l}0 \\
2\end{array}$ & $\begin{array}{l}0 \\
0\end{array}$ & $\begin{array}{l}0 \\
0\end{array}$ & $\begin{array}{r}15 \\
5\end{array}$ & $\begin{array}{l}87 \\
97\end{array}$ & $\begin{array}{l}3 \\
3\end{array}$ & $\begin{array}{l}55 \\
56\end{array}$ & N S \\
\hline \multirow{2}{*}{ 局所熱感 } & 第 1 治療期 & $\begin{array}{c}\text { F P } \\
\text { P }\end{array}$ & $\begin{array}{l}0 \\
0\end{array}$ & $\begin{array}{l}1 \\
1\end{array}$ & $\begin{array}{r}12 \\
8\end{array}$ & $\begin{array}{l}17 \\
17\end{array}$ & $\begin{array}{l}0 \\
1\end{array}$ & $\begin{array}{l}0 \\
0\end{array}$ & $\begin{array}{l}0 \\
0\end{array}$ & $\begin{array}{l}1 \\
1\end{array}$ & $\begin{array}{l}31 \\
28\end{array}$ & $\begin{array}{l}78 \\
73\end{array}$ & $\begin{array}{l}42 \\
32\end{array}$ & N S \\
\hline & 第 2 治療期 & $\underset{P}{F} \mathrm{P}$ & $\begin{array}{l}0 \\
0\end{array}$ & $\begin{array}{l}1 \\
1\end{array}$ & $\begin{array}{r}9 \\
15\end{array}$ & $\begin{array}{l}10 \\
12\end{array}$ & $\begin{array}{l}0 \\
0\end{array}$ & $\begin{array}{l}0 \\
0\end{array}$ & $\begin{array}{l}0 \\
0\end{array}$ & $\begin{array}{l}6 \\
1\end{array}$ & $\begin{array}{l}26 \\
29\end{array}$ & $\begin{array}{l}64 \\
71\end{array}$ & $\begin{array}{l}38 \\
55\end{array}$ & N S \\
\hline \multirow{2}{*}{ 腫 脹 } & 第 1 治療期 & $\begin{array}{c}\text { F P } \\
\text { P }\end{array}$ & $\begin{array}{l}0 \\
1\end{array}$ & $\begin{array}{l}1 \\
0\end{array}$ & $\begin{array}{r}15 \\
7\end{array}$ & $\begin{array}{l}35 \\
26\end{array}$ & $\begin{array}{l}0 \\
1\end{array}$ & $\begin{array}{l}0 \\
0\end{array}$ & $\begin{array}{l}0 \\
0\end{array}$ & $\begin{array}{l}1 \\
1\end{array}$ & $\begin{array}{l}52 \\
36\end{array}$ & $\begin{array}{l}57 \\
65\end{array}$ & $\begin{array}{l}31 \\
22\end{array}$ & N S \\
\hline & 第 2 治療期 & $\underset{\mathrm{P}}{\mathrm{F} P}$ & $\begin{array}{l}0 \\
0\end{array}$ & $\begin{array}{l}1 \\
2\end{array}$ & $\begin{array}{r}5 \\
20\end{array}$ & $\begin{array}{l}19 \\
24\end{array}$ & $\begin{array}{l}1 \\
0\end{array}$ & $\begin{array}{l}0 \\
0\end{array}$ & $\begin{array}{l}0 \\
0\end{array}$ & $\begin{array}{l}8 \\
1\end{array}$ & $\begin{array}{l}34 \\
47\end{array}$ & $\begin{array}{l}56 \\
53\end{array}$ & $\begin{array}{l}18 \\
47\end{array}$ & $\underset{*}{\mathrm{~F} \mathrm{P}>\mathrm{P}}$ \\
\hline \multirow{2}{*}{ 運動制限 } & 第 1 治療期 & $\underset{P}{\text { F P }}$ & $\begin{array}{l}0 \\
0\end{array}$ & $\begin{array}{l}3 \\
0\end{array}$ & $\begin{array}{l}18 \\
14\end{array}$ & $\begin{array}{l}44 \\
50\end{array}$ & $\begin{array}{l}1 \\
0\end{array}$ & $\begin{array}{l}0 \\
0\end{array}$ & $\begin{array}{l}0 \\
0\end{array}$ & $\begin{array}{l}4 \\
2\end{array}$ & $\begin{array}{l}70 \\
66\end{array}$ & $\begin{array}{l}39 \\
35\end{array}$ & $\begin{array}{l}30 \\
21\end{array}$ & $\mathrm{NS}$ \\
\hline & 第 2 治療期 & $\underset{\mathrm{P}}{\mathrm{F} \mathrm{P}}$ & $\begin{array}{l}0 \\
1\end{array}$ & $\begin{array}{l}1 \\
2\end{array}$ & $\begin{array}{l}24 \\
25\end{array}$ & $\begin{array}{l}27 \\
33\end{array}$ & $\begin{array}{l}0 \\
0\end{array}$ & $\begin{array}{l}0 \\
1\end{array}$ & $\begin{array}{l}0 \\
0\end{array}$ & $\begin{array}{l}9 \\
2\end{array}$ & $\begin{array}{l}61 \\
64\end{array}$ & $\begin{array}{l}29 \\
36\end{array}$ & $\begin{array}{l}41 \\
44\end{array}$ & $\mathrm{NS}$ \\
\hline \multirow{2}{*}{ 筋 緊 張 } & 第 1 治療期 & $\underset{P}{\mathrm{~F} P}$ & $\begin{array}{l}0 \\
0\end{array}$ & $\begin{array}{l}4 \\
0\end{array}$ & $\begin{array}{l}22 \\
16\end{array}$ & $\begin{array}{l}39 \\
41\end{array}$ & $\begin{array}{l}4 \\
0\end{array}$ & $\begin{array}{l}0 \\
0\end{array}$ & $\begin{array}{l}0 \\
0\end{array}$ & $\begin{array}{l}3 \\
2\end{array}$ & $\begin{array}{l}72 \\
59\end{array}$ & $\begin{array}{l}37 \\
42\end{array}$ & $\begin{array}{l}36 \\
27\end{array}$ & $\mathrm{~N} \mathrm{~S}$ \\
\hline & 第 2 治療期 & $\begin{array}{c}\text { F P } \\
\text { P }\end{array}$ & $\begin{array}{l}0 \\
0\end{array}$ & $\begin{array}{l}0 \\
8\end{array}$ & $\begin{array}{l}20 \\
26\end{array}$ & $\begin{array}{l}27 \\
28\end{array}$ & $\begin{array}{l}0 \\
3\end{array}$ & $\begin{array}{l}0 \\
0\end{array}$ & $\begin{array}{l}0 \\
0\end{array}$ & $\begin{array}{l}7 \\
2\end{array}$ & $\begin{array}{l}54 \\
67\end{array}$ & $\begin{array}{l}36 \\
33\end{array}$ & $\begin{array}{l}37 \\
51\end{array}$ & $\mathrm{~N} \mathrm{~S}$ \\
\hline
\end{tabular}

薬剤比較では FPが有意に優っていた(S-test, W-test).

時期比較では第 1 期に比べ，第 2 期が有意に優った (S-test).

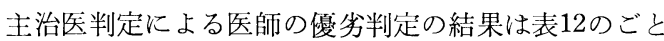
く，中央判定による結果と同様であった，

（7）患者の総合評価および患者の優劣判定

患者の総合評価の結果を表13に, 患者の優劣判定の結 果を表14に示した。

総合評価の群間比較では第 1 期, 第 2 期ともに FP 群 に有意な改善が認められ (U test), 患者内薬剂比較でも FP が有意に優った (S-test, W-test). 患者内時期比較 では第 1 期と第 2 期の間に有意差はみられなかった。

患者の優劣判定による薬剂比較では FP が有意に優 り (S-test W-test)，時期比較では第 1 期と第 2 期の間に 有意差はみられなかった。

（8）症状別重症度の分布および変化 症状別重症度の分布を表15に，変化を表16に示した。
症状別重症度の分布では, 開始時の分布には偏りはな かったが，第 1 期終了時の自発痛，第 2 期終了時の圧痛 と運動痛で FP 群が有意に軽症方向に分布していた（U test). その他の症状では，分布に有意差は認められなか った。

症状別重症度の変化では，第 1 期の自発痛で FP 群が 有意に改善し，第 2 期の腫脹で $\mathbf{P}$ 群が有意に改善してい た ( $\chi^{2}$ test $)$.

(9) 症状別患者の評価

症状別患者の評価の群間比較を表 17 ，患者内比較を表 18に示した.

群間比較では第 1 期の患部の痛み, 患部の可動性, 日 常生活で，第 2 期の患部の昼間の痛みの項目において FP 群が有意に優っていた ( U test). そのほかの項目で は有意差はみられなかった。

患者内薬剂比較では患部の痛及と日常生活の項目に拉 いて FPが有意に優った (S-test, W-test). 
表 17 患者の印象（群間比較）

\begin{tabular}{|c|c|c|c|c|c|c|c|c|c|c|c|c|c|c|}
\hline \multirow{3}{*}{ 評価項目 } & \multirow{3}{*}{ 治 療 期 } & \multirow{3}{*}{ 薬剂 } & \multicolumn{3}{|c|}{ 判 } & \multicolumn{2}{|l|}{ 定 } & \multirow{3}{*}{$\begin{array}{l}\text { 脱 } \\
\text { 落 }\end{array}$} & \multirow{3}{*}{$\begin{array}{l}\text { 合 } \\
\text { 計 }\end{array}$} & \multicolumn{4}{|c|}{$\chi^{2}$ test } & \multirow{3}{*}{$\mathrm{U}$ test } \\
\hline & & & \multirow{2}{*}{$\begin{array}{l}\text { 改 } \\
\text { 善 }\end{array}$} & \multirow{2}{*}{$\begin{array}{l}\text { や改 } \\
\text { や善 }\end{array}$} & \multirow{2}{*}{$\begin{array}{l}\text { 不 } \\
\text { 変 }\end{array}$} & \multirow{2}{*}{$\begin{array}{l}\text { や悪 } \\
\text { や化 }\end{array}$} & \multirow{2}{*}{$\begin{array}{l}\text { 覀 } \\
\text { 化 }\end{array}$} & & & \multicolumn{2}{|c|}{$\geqq$ 改 善 } & \multicolumn{2}{|c|}{ ミやや改善 } & \\
\hline & & & & & & & & & & $\%$ & & $\%$ & & \\
\hline \multirow{2}{*}{$\begin{array}{c}\text { 患部の病み } \\
\text { (冝間) }\end{array}$} & 第 1 治療期 & $\stackrel{\text { F P }}{P}$ & $\begin{array}{r}13 \\
8\end{array}$ & $\begin{array}{l}65 \\
45\end{array}$ & $\begin{array}{l}22 \\
37\end{array}$ & $\begin{array}{l}2 \\
4\end{array}$ & $\begin{array}{l}0 \\
1\end{array}$ & $\begin{array}{l}7 \\
6\end{array}$ & $\begin{array}{l}109 \\
101\end{array}$ & $\begin{array}{r}12 \\
8\end{array}$ & N S & $\begin{array}{l}72 \\
52\end{array}$ & $\underset{* *}{\mathbf{F}} \mathbf{P}>\mathbf{P}$ & $\underset{* *}{\mathrm{~F}} \mathrm{P}_{* *}$ \\
\hline & 第 2 治療期 & $\underset{P}{F P}$ & $\begin{array}{l}17 \\
12\end{array}$ & $\begin{array}{l}41 \\
53\end{array}$ & $\begin{array}{l}16 \\
23\end{array}$ & $\begin{array}{l}1 \\
4\end{array}$ & $\begin{array}{l}0 \\
3\end{array}$ & $\begin{array}{r}15 \\
5\end{array}$ & $\begin{array}{r}90 \\
100\end{array}$ & $\begin{array}{l}19 \\
12\end{array}$ & N S & $\begin{array}{l}64 \\
65\end{array}$ & N S & 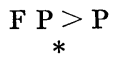 \\
\hline \multirow{2}{*}{$\begin{array}{l}\text { 患部の病み } \\
\text { (夜) }\end{array}$} & & $\begin{array}{l}\text { F P } \\
\text { P }\end{array}$ & $\begin{array}{l}16 \\
11\end{array}$ & $\begin{array}{l}49 \\
35\end{array}$ & $\begin{array}{l}32 \\
42\end{array}$ & $\begin{array}{l}2 \\
5\end{array}$ & $\begin{array}{l}1 \\
1\end{array}$ & $\begin{array}{l}9 \\
7\end{array}$ & $\begin{array}{l}109 \\
101\end{array}$ & $\begin{array}{l}15 \\
11\end{array}$ & N S & $\begin{array}{l}60 \\
46\end{array}$ & $\begin{array}{c}\mathrm{F} P>\mathrm{P} \\
+\end{array}$ & $\underset{*}{\mathrm{~F} \mathrm{P}>\mathrm{P}}$ \\
\hline & 第 2 治療期 & $\underset{P}{F}$ & $\begin{array}{l}15 \\
11\end{array}$ & $\begin{array}{l}38 \\
47\end{array}$ & $\begin{array}{l}22 \\
27\end{array}$ & $\begin{array}{l}0 \\
6\end{array}$ & $\begin{array}{l}0 \\
1\end{array}$ & $\begin{array}{r}15 \\
8\end{array}$ & $\begin{array}{r}90 \\
100\end{array}$ & $\begin{array}{l}17 \\
11\end{array}$ & N S & $\begin{array}{l}59 \\
58\end{array}$ & N S & $\begin{array}{c}\mathrm{FP}>\mathrm{P} \\
+\end{array}$ \\
\hline \multirow{2}{*}{ 圧 迫 痛 } & 第 1 治療期 & $\underset{P}{\text { F P }}$ & $\begin{array}{l}8 \\
7\end{array}$ & $\begin{array}{l}48 \\
37\end{array}$ & $\begin{array}{l}42 \\
45\end{array}$ & $\begin{array}{l}3 \\
4\end{array}$ & $\begin{array}{l}0 \\
1\end{array}$ & $\begin{array}{l}8 \\
7\end{array}$ & $\begin{array}{l}109 \\
101\end{array}$ & $\begin{array}{l}7 \\
7\end{array}$ & N S & $\begin{array}{l}51 \\
44\end{array}$ & N S & N S \\
\hline & 第 2 治療期 & $\underset{P}{F P}$ & $\begin{array}{l}12 \\
10\end{array}$ & $\begin{array}{l}35 \\
40\end{array}$ & $\begin{array}{l}26 \\
37\end{array}$ & $\begin{array}{l}2 \\
4\end{array}$ & $\begin{array}{l}0 \\
2\end{array}$ & $\begin{array}{r}15 \\
7\end{array}$ & $\begin{array}{r}90 \\
100\end{array}$ & $\begin{array}{l}13 \\
10\end{array}$ & N S & $\begin{array}{l}52 \\
50\end{array}$ & N S & N S \\
\hline \multirow{2}{*}{$\begin{array}{l}\text { 患部の可動 } \\
\text { 性 }\end{array}$} & 第 1 治療期 & $\underset{P}{F P}$ & $\begin{array}{l}6 \\
2\end{array}$ & $\begin{array}{l}41 \\
31\end{array}$ & $\begin{array}{l}48 \\
53\end{array}$ & $\begin{array}{l}3 \\
5\end{array}$ & $\begin{array}{l}0 \\
1\end{array}$ & $\begin{array}{r}11 \\
9\end{array}$ & $\begin{array}{l}109 \\
101\end{array}$ & $\begin{array}{l}6 \\
2\end{array}$ & N S & $\begin{array}{l}43 \\
33\end{array}$ & N S & $\begin{array}{c}\mathrm{E} \mathrm{P}>\mathrm{P} \\
*\end{array}$ \\
\hline & 第 2 治療期 & $\underset{P}{F P}$ & $\begin{array}{r}9 \\
10\end{array}$ & $\begin{array}{l}30 \\
39\end{array}$ & $\begin{array}{l}32 \\
37\end{array}$ & $\begin{array}{l}1 \\
5\end{array}$ & $\begin{array}{l}0 \\
1\end{array}$ & $\begin{array}{r}18 \\
8\end{array}$ & $\begin{array}{r}90 \\
100\end{array}$ & $\begin{array}{l}10 \\
10\end{array}$ & N S & $\begin{array}{l}43 \\
49\end{array}$ & $\mathrm{~N} \mathrm{~S}$ & N S \\
\hline \multirow{2}{*}{$\begin{array}{l}\text { 箩肉のこわ } \\
\text { ばり }\end{array}$} & 第 1 治療期 & $\underset{P}{F} P$ & $\begin{array}{r}11 \\
7\end{array}$ & $\begin{array}{l}36 \\
36\end{array}$ & $\begin{array}{l}48 \\
47\end{array}$ & $\begin{array}{l}3 \\
3\end{array}$ & $\begin{array}{l}0 \\
0\end{array}$ & $\begin{array}{r}11 \\
8\end{array}$ & $\begin{array}{l}109 \\
101\end{array}$ & $\begin{array}{r}10 \\
7\end{array}$ & N S & $\begin{array}{l}43 \\
43\end{array}$ & $\mathrm{~N} \mathrm{~S}$ & N S \\
\hline & 第 2 治療期 & $\underset{\mathrm{P}}{\mathrm{F} P}$ & $\begin{array}{r}11 \\
9\end{array}$ & $\begin{array}{l}29 \\
39\end{array}$ & $\begin{array}{l}30 \\
41\end{array}$ & $\begin{array}{l}2 \\
3\end{array}$ & $\begin{array}{l}0 \\
1\end{array}$ & $\begin{array}{r}18 \\
7\end{array}$ & $\begin{array}{r}90 \\
100\end{array}$ & $\begin{array}{r}12 \\
9\end{array}$ & $\mathrm{NS}$ & $\begin{array}{r}44 \\
-48\end{array}$ & N S & N S \\
\hline \multirow{2}{*}{ 日 常生活 } & 第 1 治療期 & $\underset{P}{F P}$ & $\begin{array}{r}14 \\
7\end{array}$ & $\begin{array}{l}55 \\
44\end{array}$ & $\begin{array}{l}30 \\
39\end{array}$ & $\begin{array}{l}3 \\
4\end{array}$ & $\begin{array}{l}0 \\
0\end{array}$ & $\begin{array}{l}7 \\
7\end{array}$ & $\begin{array}{l}109 \\
101\end{array}$ & $\begin{array}{r}13 \\
7\end{array}$ & N S & $\begin{array}{l}63 \\
50\end{array}$ & $\begin{array}{c}\mathbf{F} \mathbf{P}>\mathbf{P} \\
+\end{array}$ & $\underset{*}{\mathrm{~F} \mathrm{P}>\mathrm{P}}$ \\
\hline & 第 2 治療期 & $\begin{array}{c}\text { F P } \\
P\end{array}$ & $\begin{array}{l}14 \\
14\end{array}$ & $\begin{array}{l}38 \\
50\end{array}$ & $\begin{array}{l}21 \\
27\end{array}$ & $\begin{array}{l}1 \\
3\end{array}$ & $\begin{array}{l}0 \\
1\end{array}$ & $\begin{array}{r}16 \\
5\end{array}$ & $\begin{array}{r}90 \\
100\end{array}$ & $\begin{array}{l}16 \\
14\end{array}$ & N S & $\begin{array}{l}58 \\
64\end{array}$ & N S & $\mathrm{NS}$ \\
\hline
\end{tabular}

患者内時期比較では患部の痛み, 患部の可動性, 日常 生活の項目に扣いて第 2 期が有意に優った（S-test, Wtest).

(10) 疾患別評価

疾患別の全般改善度, 全般有用度, 医師の優劣判定を 表19から表23に示した。

疾患別全般改善度では表19, 表20のごとく, 群間比較 では肩関節周囲炎に括いて，第 2 期で FP 群が有意に優 り (U test), 患者内薬剤比較でも肩関節周囲炎に拈い て, FPが有意に優った (S-test, W-test). 他の疾患では 有意差はみられなかった。

疾患別全般有用度では表 21 , 表 22 のごとく，群間比較 および患者内薬剂比較とも有意差はみられなかった。

医師の優劣判定においては表23のごとく, 肘関節周囲 炎で FP が有意に優った (S-test, W-test). その他の疾患 では有意差はみられなかった。

11）臨床検查

投与前後に臨床検查が実施された症例は 11 例であっ た. 1 例に GOT $(106 \rightarrow 206)$, GPT $(97 \rightarrow 190)$ の上昇 がみられたが，本症例は肝硬変を合併して和り，主治医
により薬殽との因果関係はないと判断された.

\section{考 察}

外傷, 非外傷性を問わず，整形外科領域の疼痛性疾患 に対し, 非ステロイド抗炎症鎮痛剂の内服や坐剤の有効 性は認められているが，胃腸障害などの副作用が報告さ れている。

そこで，限局した症状に対しては非ステロイド抗炎症 剂を局所に直接作用させることができれば，これら全身 性副作用を回避でき, 有用性は高いと考えられる。

今回使用したアドフロベン (FP) は, 非ステロイド抗 炎症鎮痛剂として内服で使用されているフルルビプロフ ェンを含有する外用貼付剂である.

本剂は, 薬効薬理試験で, ラットでのカラゲニン足蹠 浮腫, 外傷性強打浮腫, アジュバント関節炎, ホルマリ ンペレット法による背部皮下の肉芽形成，モルモットで の紫外線紅斑などに対する抗炎症作用を有し ${ }^{1)}$, ラット でのランダルセリット法で鎮痛作用を有することが認め られている21.

一方，ウサギおよびモルモットを用いた実験での皮膚 
1 ）患者内薬剂比較

表 18 患者の印象（患者内比較）

\begin{tabular}{|c|c|c|c|c|c|c|c|c|c|c|c|c|c|}
\hline \multirow{2}{*}{ 評価項目 } & \multicolumn{4}{|c|}{ F P } & \multicolumn{3}{|c|}{$\mathbf{P}$} & \multirow{2}{*}{ 脱 落 } & \multirow{2}{*}{ 合 計 } & \multirow{2}{*}{$>\%$} & \multirow{2}{*}{$<\%$} & \multirow{2}{*}{ S-test } & \multirow{2}{*}{$\mathrm{W}$-test } \\
\hline & $\gg \gg$ & $\gg$ & $>$ & $=$ & $<$ & $\ll$ & $<$ & & & & & & \\
\hline $\begin{array}{c}\text { 患部の痛み } \\
\text { (昼間) }\end{array}$ & 3 & 6 & 42 & 98 & 20 & 1 & 0 & 20 & 190 & 27 & 11 & $\underset{* * *}{\mathrm{~F}} \mathrm{P}_{* * \mathrm{P}}^{\mathrm{P}}$ & $\underset{* * *}{\mathrm{~F}} \mathrm{P}^{\mathrm{P}}>\mathrm{P}$ \\
\hline $\begin{array}{c}\text { 患部の病 又 } \\
\text { (夜間) }\end{array}$ & 2 & 4 & 44 & 96 & 19 & 2 & 0 & 23 & 190 & 26 & 11 & $\underset{* * *}{\mathrm{~F}} \underset{\mathrm{P}}{\mathrm{P}>\mathrm{P}}$ & $\underset{* * *}{\mathrm{~F}} \underset{ }{\mathrm{P}}>\mathrm{P}$ \\
\hline 圧 迫 痛 & 1 & 6 & 37 & 93 & 28 & 2 & 0 & 23 & 190 & 23 & 16 & N S & $\underset{*}{\mathrm{~F} \mathrm{P}>\mathrm{P}}$ \\
\hline $\begin{array}{l}\text { 患部の可動 } \\
\text { 性 }\end{array}$ & 0 & 6 & 24 & 112 & 18 & 2 & 0 & 28 & 190 & 16 & 11 & N S & N S \\
\hline $\begin{array}{l}\text { 筫肉のこわ } \\
\text { ばり }\end{array}$ & 1 & 4 & 26 & 103 & 27 & 2 & 0 & 27 & 190 & 16 & 15 & $\mathrm{~N} \mathrm{~S}$ & N S \\
\hline 日 常 生 活 & 0 & 5 & 35 & 106 & 22 & 1 & 0 & 21 & 190 & 21 & 12 & $\underset{*}{\mathrm{~F} \mathrm{P}>\mathrm{P}}$ & $\underset{*}{\mathrm{~F} \mathrm{P}>\mathrm{P}}$ \\
\hline
\end{tabular}

2）患者内時期比較

\begin{tabular}{|c|c|c|c|c|c|c|c|}
\hline \multirow{2}{*}{ 評価項目 } & \multicolumn{4}{|c|}{ 第 1 治療期 } & \multicolumn{3}{|c|}{ 第 2 治療期 } \\
\hline & $\gg \gg$ & $\gg$ & $>$ & $=$ & $<$ & $\ll$ & $\ll \ll$ \\
\hline $\begin{array}{c}\text { 患部の病み } \\
\text { (冝間) }\end{array}$ & 3 & 4 & 20 & 98 & 42 & 3 & 0 \\
\hline $\begin{array}{l}\text { 患部の痛又 } \\
\text { (夜)間) }\end{array}$ & 2 & 3 & 21 & 96 & 42 & 3 & 0 \\
\hline 圧 迫 痛 & 1 & 3 & 28 & 93 & 37 & 5 & 0 \\
\hline $\begin{array}{l}\text { 患部の可動 } \\
\text { 性 }\end{array}$ & 0 & 2 & 10 & 112 & 32 & 6 & 0 \\
\hline $\begin{array}{l}\text { 筋肉のこわ } \\
\text { ばり }\end{array}$ & 1 & 3 & 19 & 103 & 34 & 3 & 0 \\
\hline 日常生活 & 0 & 3 & 18 & 106 & 39 & 3 & 0 \\
\hline
\end{tabular}

刺激性, 光毒性および皮膚アレルギー性は認められず, 安全性が確認されている ${ }^{2,3)}$ 。 たラットを用いた吸収 試験で,フルルビプロフェンの炎症組織中への高濃度の 移行が認められている4!．ヒトの皮覤に貼付した場合に も吸収され，血中に移行するが，内服に比べ著しく低い ことが認められている5).

これらの実験結果から，FP は局所貼付により主剂フ ルルビプロフェンが経皮吸収され，局所の炎症および疼 痛に効果を現し，しかも経口投与と異なり，血中への移 行がわずかであることから全身への影響が少ないであろ らと推定された.

すでにわれわれが実施した 143 例の臨床試用6)におい て, 捻挫, 挫傷, 打撲などの外傷性疾患で $87.5 \%$, 変形 性関節症, 関節炎, 慢性関節りウマチなどの非外傷性疾 患で72.0\%に改善を認めている.

本二重盲検試験に先だら FP の有効性を明らかに判定

\begin{tabular}{|c|c|c|c|c|c|}
\hline 兄 落 & 合計 & $>\%$ & $<\%$ & S-test & $\mathrm{W}$-test \\
\hline 20 & 190 & 14 & 24 & $\begin{array}{l}\text { 第 } 1 \\
\text { 治療期 } \\
\end{array}$ & N S \\
\hline 23 & 190 & 14 & 24 & $\begin{array}{c}\text { 第 } 1 \text { 治療期 }<\text { 治療期 } \\
* \\
*\end{array}$ & $\begin{array}{c}\text { 第 } 1 \\
\text { 治療期 } \\
+ \text { 第 } \\
+ \text { 治療期 } \\
\end{array}$ \\
\hline 23 & 190 & 17 & 22 & N S & N S \\
\hline 28 & 190 & 6 & 20 & 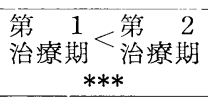 & 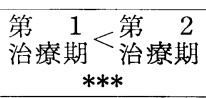 \\
\hline 27 & 190 & 12 & 19 & 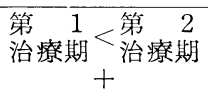 & N S \\
\hline 21 & 190 & 11 & 22 & $\begin{array}{c}\text { 第 } 1 \\
\text { 治療期 }\end{array}$ & 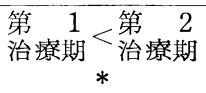 \\
\hline
\end{tabular}

できる評価方法を確認する目的で非外傷性疼痛性疾患に 対し，基剤（P）を対照とした小規模な二重盲検交差試 験を実施した。その結果，51例が集計解析され，医師の 評価は群間比較では推計学的な差がみられなかったが, 群内比較では FPが P よりも有意に優る結果が得られた (McNemar test, $\mathrm{P}<0.05)$. また医師の優劣判定では, $\mathrm{FP}$ が優れる比率が $\mathrm{P}$ をまわって抢り, 患者の優劣判 定に沶いても FPが優れる比率が P を上まわっていた。

しかし少数例のために推計学的な差を検出するにはいた らなかった。

外用貼付剂では基剤が単に薬剤を保持する役目にとど まらず，基剤による患部に与える感触も有効性に大きな 役割を示すことから，基剤の果たす役割は無視できない と考えられた。

本試験では, 予備試験の結果をふまえ, 評価基準, 評 価尺度などに若干の修正を加えて, 自然治瘉の傾向の少 
表 19 疾患別全般改善度（群間比較）

\begin{tabular}{|c|c|c|c|c|c|c|c|c|c|c|c|c|c|c|c|c|c|}
\hline & & & 薬 & & & 全 般 & 改 & 善 度 & & & 脱 & 合 & & & est & & \\
\hline & 置 別 項 目 & 治 療 期 & & 著改 & & 軽改 & & & 悪 & 重悪 & & & $\geqq$ & 女善 & \軽 & 定改善 & $\underset{\text { test }}{\mathrm{U}}$ \\
\hline & & & 郕 & 明善 & 善 & 度善 & 変 & 度化 & 化 & 化 & 落 & 計 & $\%$ & & $\%$ & & \\
\hline & & 第 1 治療期 & $\begin{array}{c}\text { F P } \\
P\end{array}$ & $\begin{array}{l}1 \\
0\end{array}$ & $\begin{array}{l}6 \\
1\end{array}$ & $\begin{array}{l}17 \\
12\end{array}$ & $\begin{array}{l}9 \\
8\end{array}$ & $\begin{array}{l}1 \\
1\end{array}$ & $\begin{array}{l}0 \\
0\end{array}$ & $\begin{array}{l}0 \\
0\end{array}$ & $\begin{array}{l}0 \\
1\end{array}$ & $\begin{array}{l}34 \\
23\end{array}$ & $\begin{array}{r}21 \\
4\end{array}$ & N S & $\begin{array}{l}71 \\
57\end{array}$ & N S & N S \\
\hline & 为任任 & 第 2 治療期 & $\underset{P}{F P}$ & $\begin{array}{l}0 \\
0\end{array}$ & $\begin{array}{r}8 \\
13\end{array}$ & $\begin{array}{r}6 \\
13\end{array}$ & $\begin{array}{l}3 \\
3\end{array}$ & $\begin{array}{l}1 \\
1\end{array}$ & $\begin{array}{l}0 \\
0\end{array}$ & $\begin{array}{l}0 \\
0\end{array}$ & $\begin{array}{l}2 \\
1\end{array}$ & $\begin{array}{l}20 \\
31\end{array}$ & $\begin{array}{l}40 \\
42\end{array}$ & N S & $\begin{array}{l}70 \\
84\end{array}$ & N S & N S \\
\hline & & 第 1 治療期 & $\begin{array}{c}\text { F P } \\
P\end{array}$ & $\begin{array}{l}0 \\
0\end{array}$ & $\begin{array}{l}5 \\
5\end{array}$ & $\begin{array}{l}14 \\
11\end{array}$ & $\begin{array}{l}4 \\
8\end{array}$ & $\begin{array}{l}0 \\
1\end{array}$ & $\begin{array}{l}0 \\
0\end{array}$ & $\begin{array}{l}0 \\
0\end{array}$ & $\begin{array}{l}3 \\
2\end{array}$ & $\begin{array}{l}26 \\
27\end{array}$ & $\begin{array}{l}19 \\
19\end{array}$ & N S & $\begin{array}{l}73 \\
59\end{array}$ & N S & N S \\
\hline & 屑关䬣周井炎 & 第 2 治療期 & $\underset{\mathrm{P}}{\mathrm{F} P}$ & $\begin{array}{l}1 \\
0\end{array}$ & $\begin{array}{l}9 \\
5\end{array}$ & $\begin{array}{l}10 \\
16\end{array}$ & $\begin{array}{l}0 \\
2\end{array}$ & $\begin{array}{l}0 \\
0\end{array}$ & $\begin{array}{l}0 \\
0\end{array}$ & $\begin{array}{l}0 \\
0\end{array}$ & $\begin{array}{l}4 \\
1\end{array}$ & $\begin{array}{l}24 \\
24\end{array}$ & $\begin{array}{l}42 \\
21\end{array}$ & N S & $\begin{array}{l}83 \\
88\end{array}$ & N S & $\underset{*}{\mathrm{FP}}>\mathrm{P}$ \\
\hline & & 第 1 治療期 & $\underset{P}{F} \mathbf{P}$ & $\begin{array}{l}0 \\
1\end{array}$ & $\begin{array}{l}3 \\
1\end{array}$ & $\begin{array}{l}7 \\
5\end{array}$ & $\begin{array}{l}2 \\
4\end{array}$ & $\begin{array}{l}0 \\
0\end{array}$ & $\begin{array}{l}0 \\
0\end{array}$ & $\begin{array}{l}0 \\
0\end{array}$ & $\begin{array}{l}0 \\
0\end{array}$ & $\begin{array}{l}12 \\
11\end{array}$ & $\begin{array}{l}25 \\
18\end{array}$ & N S & $\begin{array}{l}83 \\
64\end{array}$ & N S & N S \\
\hline & 的奇即问分灭 & 第 2 治療期 & $\begin{array}{c}\text { F P } \\
\mathrm{P}\end{array}$ & $\begin{array}{l}2 \\
0\end{array}$ & $\begin{array}{l}3 \\
4\end{array}$ & $\begin{array}{l}3 \\
6\end{array}$ & $\begin{array}{l}2 \\
1\end{array}$ & $\begin{array}{l}0 \\
0\end{array}$ & $\begin{array}{l}0 \\
0\end{array}$ & $\begin{array}{l}0 \\
0\end{array}$ & $\begin{array}{l}1 \\
1\end{array}$ & $\begin{array}{l}11 \\
12\end{array}$ & $\begin{array}{l}45 \\
33\end{array}$ & N S & $\begin{array}{l}73 \\
83\end{array}$ & N S & $\mathrm{NS}$ \\
\hline 患 & $z 0+0+2$ & 第 1 治療期 & $\begin{array}{c}\text { F P } \\
P\end{array}$ & $\begin{array}{l}0 \\
0\end{array}$ & $\begin{array}{l}2 \\
1\end{array}$ & $\begin{array}{l}1 \\
1\end{array}$ & $\begin{array}{l}0 \\
0\end{array}$ & $\begin{array}{l}0 \\
0\end{array}$ & $\begin{array}{l}0 \\
0\end{array}$ & $\begin{array}{l}0 \\
0\end{array}$ & $\begin{array}{l}0 \\
0\end{array}$ & $\begin{array}{l}3 \\
2\end{array}$ & $\begin{array}{l}67 \\
50\end{array}$ & N S & $\begin{array}{l}100 \\
100\end{array}$ & N S & N S \\
\hline 分 & 周囲炎 & & $\begin{array}{c}\text { F P } \\
\text { P }\end{array}$ & $\begin{array}{l}0 \\
0\end{array}$ & $\begin{array}{l}0 \\
3\end{array}$ & $\begin{array}{l}1 \\
0\end{array}$ & $\begin{array}{l}0 \\
0\end{array}$ & $\begin{array}{l}0 \\
0\end{array}$ & $\begin{array}{l}0 \\
0\end{array}$ & $\begin{array}{l}0 \\
0\end{array}$ & $\begin{array}{l}0 \\
0\end{array}$ & $\begin{array}{l}1 \\
3\end{array}$ & $\begin{array}{r}0 \\
100\end{array}$ & N S & $\begin{array}{l}100 \\
100\end{array}$ & N S & $\mathrm{N} \mathrm{S}$ \\
\hline & & 第 1 治療期 & $\underset{\mathrm{P}}{\mathrm{F} P}$ & $\begin{array}{l}2 \\
2\end{array}$ & $\begin{array}{l}3 \\
3\end{array}$ & $\begin{array}{l}5 \\
5\end{array}$ & $\begin{array}{l}2 \\
4\end{array}$ & $\begin{array}{l}1 \\
0\end{array}$ & $\begin{array}{l}0 \\
1\end{array}$ & $\begin{array}{l}0 \\
0\end{array}$ & $\begin{array}{l}4 \\
1\end{array}$ & $\begin{array}{l}17 \\
16\end{array}$ & $\begin{array}{l}29 \\
31\end{array}$ & N S & $\begin{array}{l}59 \\
63\end{array}$ & N S & $\mathrm{NS}$ \\
\hline & 畔 & 第 2 治療期 & $\underset{P}{F ~ P}$ & $\begin{array}{l}2 \\
1\end{array}$ & $\begin{array}{l}1 \\
4\end{array}$ & $\begin{array}{l}7 \\
1\end{array}$ & $\begin{array}{l}0 \\
4\end{array}$ & $\begin{array}{l}0 \\
1\end{array}$ & $\begin{array}{l}0 \\
0\end{array}$ & $\begin{array}{l}0 \\
0\end{array}$ & $\begin{array}{l}4 \\
2\end{array}$ & $\begin{array}{l}14 \\
13\end{array}$ & $\begin{array}{l}21 \\
38\end{array}$ & N S & $\begin{array}{l}71 \\
46\end{array}$ & N S & $\mathrm{N} \mathrm{S}$ \\
\hline & & 第 1 治療期 & $\underset{\mathrm{P}}{\mathrm{F} P}$ & $\begin{array}{l}0 \\
0\end{array}$ & $\begin{array}{l}3 \\
2\end{array}$ & $\begin{array}{l}5 \\
6\end{array}$ & $\begin{array}{l}1 \\
3\end{array}$ & $\begin{array}{l}0 \\
0\end{array}$ & $\begin{array}{l}0 \\
0\end{array}$ & $\begin{array}{l}0 \\
0\end{array}$ & $\begin{array}{l}0 \\
0\end{array}$ & $\begin{array}{r}9 \\
11\end{array}$ & $\begin{array}{l}33 \\
18\end{array}$ & N S & $\begin{array}{l}89 \\
73\end{array}$ & N S & $\mathrm{N} \mathrm{S}$ \\
\hline & 垻月月夗訨信碎 & 第 2 治療期 & $\begin{array}{l}\text { F P } \\
\text { P }\end{array}$ & $\begin{array}{l}1 \\
0\end{array}$ & $\begin{array}{l}4 \\
3\end{array}$ & $\begin{array}{l}3 \\
5\end{array}$ & $\begin{array}{l}2 \\
1\end{array}$ & $\begin{array}{l}0 \\
0\end{array}$ & $\begin{array}{l}0 \\
0\end{array}$ & $\begin{array}{l}0 \\
0\end{array}$ & $\begin{array}{l}1 \\
0\end{array}$ & $\begin{array}{r}11 \\
9\end{array}$ & $\begin{array}{l}45 \\
33\end{array}$ & N S & $\begin{array}{l}73 \\
89\end{array}$ & N S & $\mathrm{N} \mathrm{S}$ \\
\hline & & 第 1 治療期 & $\underset{\mathrm{P}}{\text { F P }}$ & $\begin{array}{l}0 \\
0\end{array}$ & $\begin{array}{l}1 \\
3\end{array}$ & $\begin{array}{l}3 \\
2\end{array}$ & $\begin{array}{l}4 \\
4\end{array}$ & $\begin{array}{l}0 \\
0\end{array}$ & $\begin{array}{l}0 \\
0\end{array}$ & $\begin{array}{l}0 \\
0\end{array}$ & $\begin{array}{l}0 \\
2\end{array}$ & $\begin{array}{r}8 \\
11\end{array}$ & $\begin{array}{l}13 \\
27\end{array}$ & N S & $\begin{array}{l}50 \\
45\end{array}$ & N S & $\mathrm{NS}$ \\
\hline & & 第 2 治療期 & $\underset{P}{\text { F P }}$ & $\begin{array}{l}1 \\
0\end{array}$ & $\begin{array}{l}4 \\
3\end{array}$ & $\begin{array}{l}1 \\
3\end{array}$ & $\begin{array}{l}0 \\
1\end{array}$ & $\begin{array}{l}0 \\
1\end{array}$ & $\begin{array}{l}0 \\
0\end{array}$ & $\begin{array}{l}0 \\
0\end{array}$ & $\begin{array}{l}3 \\
0\end{array}$ & $\begin{array}{l}9 \\
8\end{array}$ & $\begin{array}{l}56 \\
38\end{array}$ & N S & $\begin{array}{l}67 \\
75\end{array}$ & N S & N S \\
\hline
\end{tabular}

表 20 疾患別全般改善度（患者内薬剂比較）

\begin{tabular}{|c|c|c|c|c|c|c|c|c|c|c|c|c|c|c|}
\hline & \multirow{2}{*}{ 項 } & \multicolumn{4}{|c|}{ F P } & \multicolumn{3}{|c|}{$\mathrm{P}$} & \multirow{2}{*}{ 脱落 } & \multirow{2}{*}{ 合計 } & \multirow{2}{*}{$>\%$} & \multirow{2}{*}{$<\%$} & \multirow{2}{*}{ S-test } & \multirow{2}{*}{$\mathrm{W}$-test } \\
\hline & & $\gg \gg$ & $\gg$ & $>$ & $=$ & $<$ & $\ll$ & $\ll \ll$ & & & & & & \\
\hline \multirow{4}{*}{$\begin{array}{l}\text { 疾 } \\
\text { 患 } \\
\text { 分 }\end{array}$} & 変 形 性 関 節 症 & 0 & 4 & 12 & 17 & 11 & 4 & 0 & 3 & 51 & 31 & 29 & N S & N S \\
\hline & 肩 関 節 周 囲 炎 & 0 & 1 & 17 & 18 & 7 & 0 & 0 & 5 & 48 & 38 & 15 & $\mathrm{~F} \underset{*}{\mathrm{P}>\mathrm{P}}$ & $\begin{array}{c}\mathrm{F} \mathrm{P}>\mathrm{P} \\
*\end{array}$ \\
\hline & 时 関 節 周囲炎 & 0 & 0 & 8 & 9 & 4 & 0 & 0 & 2 & 23 & 35 & 17 & N S & N S \\
\hline & その他の関節周国炎 & 0 & 0 & 0 & 3 & 1 & 0 & 0 & 0 & 4 & 0 & 25 & N S & N S \\
\hline \multirow{3}{*}{ 類 } & 腱䈰 & 0 & 0 & 9 & 9 & 3 & 0 & 0 & 6 & 27 & 33 & 11 & $\mathrm{~N} \mathrm{~S}$ & $\mathrm{NS}$ \\
\hline & 頸 肩 腕 症 候 群 & 0 & 0 & 5 & 13 & 1 & 0 & 0 & 1 & 20 & 25 & 5 & $\mathrm{NS}$ & N S \\
\hline & そ の 他 & 1 & 0 & 4 & 6 & 2 & 1 & 0 & 3 & 17 & 29 & 18 & $\mathrm{~N} \mathrm{~S}$ & $\mathrm{NS}$ \\
\hline
\end{tabular}


表 21 疾患別全般有用度（群間比較）

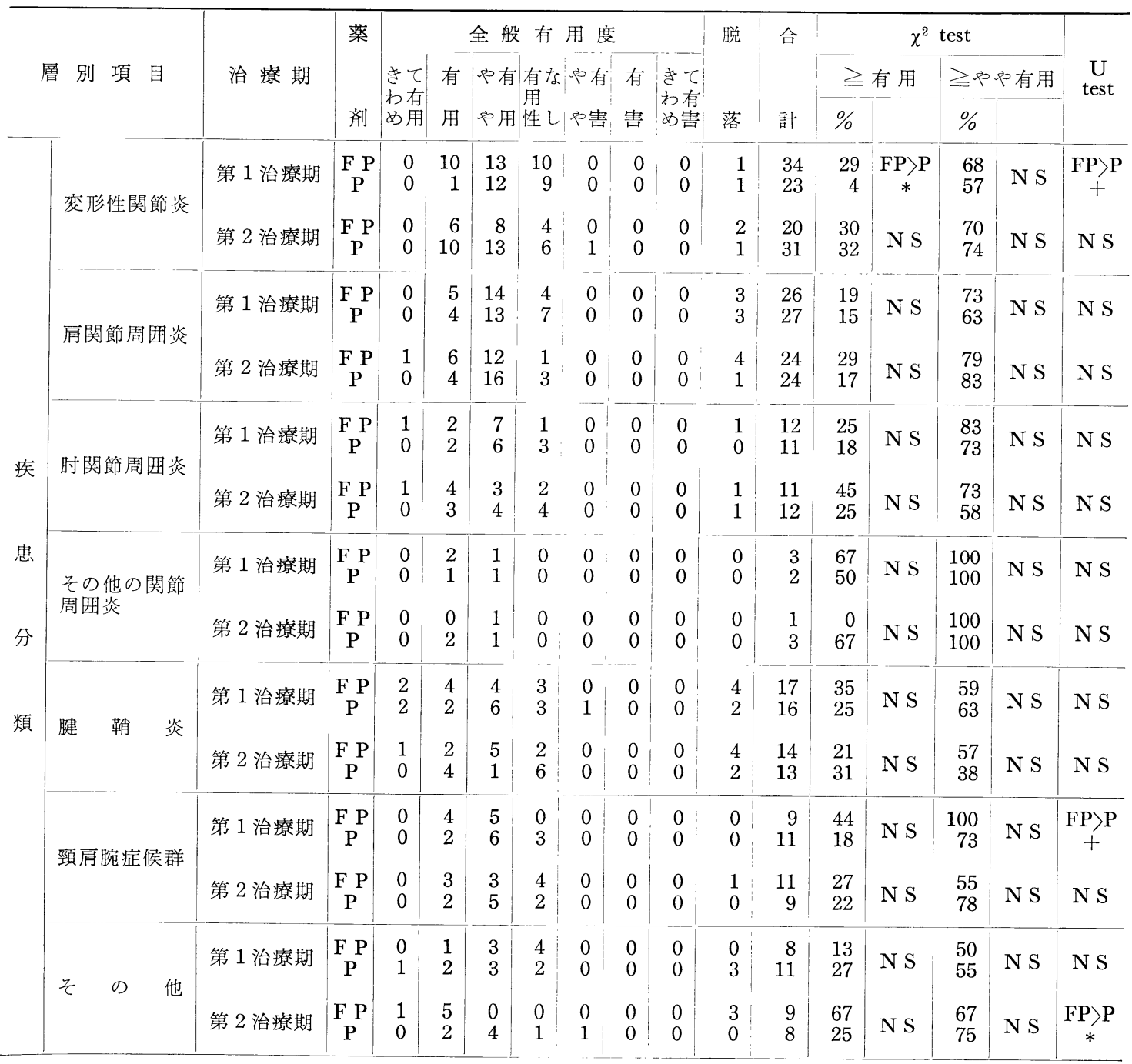

表 22 疾患別全般有用度（患者内薬剤比較）

\begin{tabular}{|c|c|c|c|c|c|c|c|c|c|c|c|c|c|c|}
\hline & 叫 项 & & $\mathrm{F}$ & & & & $\mathrm{P}$ & & & & & & & \\
\hline & - & $\gg \gg$ & $\gg$ & $>$ & $=$ & $<$ & $\ll$ & $\ll$ & 脱 洛 & 合 計 & $>\%$ & $<\%$ & S-test & W-test \\
\hline & 変 形 性 関 節 症 & 0 & 5 & 15 & 14 & 11 & 3 & 0 & 3 & 51 & 39 & 27 & N S & N S \\
\hline 疾 & 肩 関 節 周 囲 炎 & 0 & 2 & 15 & 15 & 11 & 0 & 0 & 5 & 48 & 35 & 23 & N S & N S \\
\hline 患 & 时 関 節 周毌炎 & 0 & 1 & 10 & 7 & 2 & 1 & 0 & 2 & 23 & 48 & 13 & $\underset{*}{\mathrm{~F}} \underset{*}{P}>\mathrm{P}$ & N S \\
\hline 分 & その他の関節周囲炎 & 0 & 0 & 1 & 2 & 1 & 0 & 0 & 0 & 4 & 25 & 25 & N S & N S \\
\hline 頪 & 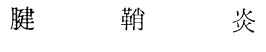 & 0 & 2 & 8 & 7 & 4 & 0 & 0 & 6 & 27 & 37 & 15 & N S & N S \\
\hline & 頸 屃詺 症 候 群 & 0 & 0 & 6 & 11 & 1 & 1 & 0 & 1 & 20 & 30 & 10 & N S & N S \\
\hline & そ の & 1 & 0 & 5 & 4 & 3 & 1 & 0 & 3 & 17 & 35 & 24 & N S & N S \\
\hline
\end{tabular}


表 23 疾患別医師の優劣判定（薬剤比較）

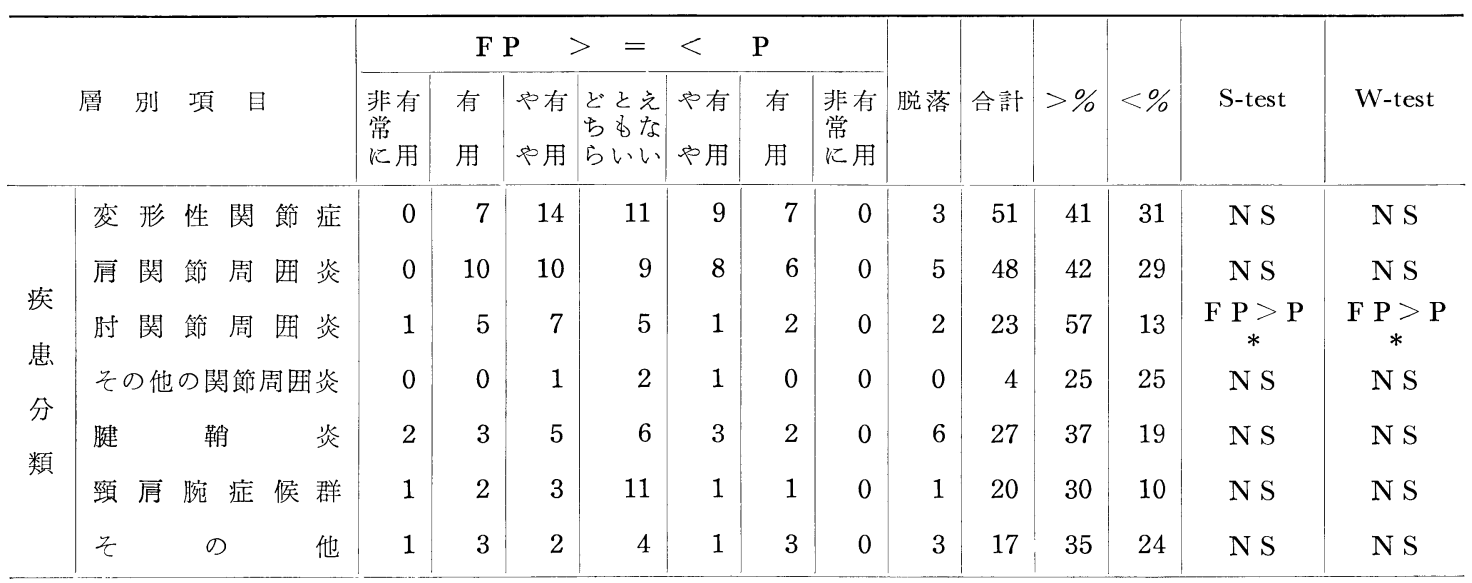

ない持続性疼痛疾患を対象に，二重盲検交差試験法によ り基剤（P）との比較を実施した。

全般改善度の群間比較についてみると, 第 1 期, 第 2 期とも FP 群が P 群よりも優る傾向にはあったが，有意 差を認めるまでにはいたらなかった。第 2 期の判定で は, 開始時を基準にしているので, 第 2 期の $\mathrm{P}$ 群は第 1 期には FP が使用されているため, 全体に第 1 期より改 善率は高く現れている。これは患者内時期比較で有意に 第 2 期がよくなっている理由の 1 つにあげられるが，外 用剂使用に対する慣れの現象が第 2 期に有利に働いてい るかもしれない。休薬が 1 日と短い懸念はあったが，患 者内薬剂比較では，FP の医らが有意に優れている結果 が得られた。

副作用は第 1 期で, FP 群 3 例 ( $3 \%$ ), P 群 で 1 例 ( $1 \%)$, 第 2 期で, $P$ 群 5 例 ( $5 \%$ ) にかぶれ，かゆみ などが認められ，全般的に副作用発生例は少なかった。 推計学的には, 第 2 期で有意に FP 群の安全性が高い結 果が得られたが，含有されているフルルビプロフェンが 副作用の発生を抑制しているためかどらかは疑問であ る.

全般改善度，概括安全度から総合的に判断した全般有 用度では，群間比較で第 1 期において FP 群が有意に優 れ，第 2 期では FP 群が優る傾向にあった。このことは 先に述べた理由により第 2 期の $\mathrm{P}$ 群でやや有用と判定さ れた例が多くなったためであろら。患者内薬剂比較では 全般改善度と同様に FP が有意に優れている結果が得ら れた。

医師の優劣判定では, FP の優れる比率が $41 \%$ であっ たのに対し，Pが優れる比率は $24 \%$ で, 推計学的に FP の汇らが有意に優れていた。

患者のアンケートより得られた総合評価についてみる と, 群間比較で第 1 期, 第 2 期とも FP 群が有意に優っ ていた．患者内薬羭比較でもFP のほうが有意に優り, 患者の優劣判定でも, 総合評価と同様に FP が有意に優
れていることが認められた。

症状別重症度の分布についてみると，第 1 期に沶いて 自発痛で，また第 2 期に和いて圧痛と運動痛で FP の有 効性が P に比べ明らかであり，このことはフルルビプロ フェンの疼痛に対する効果が現れたものと考えられた。

症状別重症度の変化では, 第 1 期に打汗る自発痛の改 善例が FP に多かった．第 2 期に拀いては腫脹の改善例 が $\mathrm{P}$ 群に多く認められたが，第 2 期の効果判定が治療開 始時と比較して行われている結果によるものと考兄られ る.

項目別患者の評価でみると, 患部の痛み, 患部の可動 性, 日常生活の項目で, FP 群が有意に改善している結 果が示されている。

疾患別全般改善度をみると, 患者内薬剂比較では, 肩 関節周囲炎に颃いて FP が有意に優り, 変形性関節症, 肘関節周囲炎, 腱鞘炎, 頸肩腕症候群で FP の優れる比 率がPを上まわっていた。

疾患別にみた全般有用度の患者内薬剂比較および医師 の優劣判定に沶いても, それぞれの疾患で FP の優れる 比率が $\mathrm{P}$ 上まわっていた。

以上の結果より，FP は P と比較して，明らかに臨床 効果が優れ，とくに疼痛に対し有効であり，全身に対す る副作用もないことから, 非ステロイド抗炎症鎮痛剂を 含有する外用貼付剂として臨床的価值は高いものと考兄 られる。

\section{結 語}

フルルビプロフェンを含有する外用貼付剂アドフロベ ン (FP) の有用性を, 整形外科領域の持続性有痛疾患を 対象にして, 基剤 $(\mathrm{P})$ との二重盲検交差試験により比 較検討した。

(1) 解析対象例数は, 第 1 治療期 210 例, 第 2 治療期 190 例であった。

(2) 全般改善度は, 群間比較では第 1 治療期, 第 2 治 
療期とも FP 群が優る傾向にあり, 患者内薬剤比較では FP が有意優った。

(3) 副作用の発現例は, FP, P とも少なく, 第 1 治療 期に怙ける FP で 3 例（3\%)，P で1例（1\%), 第 2 治療に执いてはFP には認められず，P で5例（5\%) であった。いずれも貼付部位の皮膚症状であった。

(4) 全般有用度では, 第 1 治療期の群間比較之, 患者 内薬剂比較で FP が有意に優り, FP の有用性が認めら れた。

(5) 医師の優劣判定でも, FP が有意に優り, FP の有 用性が認められた。

(6) 症状別にみると, 自発痛, 圧痛, 運動痛などの疼 痛に対し FP の効果が認められた。

以上の結果より, アドフロベンは整形外科領域の疼痛 疾患飞対する局所療法剤として有用な薬剂と考光られ る.

\section{文 献}

1）舛本省三, 秋葉哲朗, 奥村 誠, 市川清之進, 橋 本喜信：Flurbiprofen 外用剤 (FP-A) の抗炎症作
用. 医薬品研究。投稿中.

2）北川晴雄，酒井 健，斉藤晴夫，森 政雄, 田添 龍一, 杉林毅宏, 野村 明 : 2-(2-Fluoro-4-Biphenylyl)-Propionic Acid (Flurbiprofen)の皮覤 適用比上る抗炎症・鎮痛作用及び皮䖉刺激試驗。 医薬品研究。投稿中.

3）北川晴雄, 酒井 健, 斉藤晴夫, 森 政雄, 田 添龍一, 杉村毅宏, 野村 明, 森時弘敬, 奥田敏 明, 斉藤勝弘：抗炎症薬 2-(2-fluoro-4-biphenytyl) propionic acid (Flurbiprofen) の皮屑適用飞 打计当毒性試験。未発表。

4) 坂井康雄, 東野正男, 小鸠 博, 松村 譲, 浅田 与志昭，宇田一正，橋本喜信：ラット皮覤に適用 した Flurbiprofen (FP) の吸収, 分布, 代謝扰上 び排泄。医薬品研究。投稿中。

5）清水正啓, 河原賢二, 松村美佐子, 木村一彦：邓 ドフロベンの第I 相臨床試験。未発表。

6) 小松原良雄, 木村正己, 辻本正記：整形外科領域 に扰けるフルルビプロフェン含有貼付剤アドフロ ベンの臨床評価。薬理と治療。投稿中。

7）コントローラー委員会：薬効評価シスラム解説書 (第 2 部). 第 2 部 クロスオーバー法 (D5). 臨 床評価 4: 549-583, 1976. 